Volume 117

Issue 2 Dickinson Law Review - Volume 117,

2012-2013

$10-1-2012$

\title{
Guantanamo Bay and the Conflict of Ethical Lawyering
}

Dana Carver Boehm

Follow this and additional works at: https://ideas.dickinsonlaw.psu.edu/dlra

\section{Recommended Citation}

Dana C. Boehm, Guantanamo Bay and the Conflict of Ethical Lawyering, 117 Dick. L. ReV. 283 (2012). Available at: https://ideas.dickinsonlaw.psu.edu/dlra/vol117/iss2/2

This Article is brought to you for free and open access by the Law Reviews at Dickinson Law IDEAS. It has been accepted for inclusion in Dickinson Law Review by an authorized editor of Dickinson Law IDEAS. For more information, please contact lja10@psu.edu. 


\title{
Articles
}

\section{Guantanamo Bay and the Conflict of Ethical Lawyering}

\section{Dana Carver Boehm*}

\begin{abstract}
The Guantanamo Bay military commissions have been the subject of intense national and international debate since they were announced months after the September 11th attacks. This important debate largely has focused on the perennial tension between liberty and security on the one hand and the somewhat technical legal questions regarding the constitutionality of prescribed procedures on the other. As significant as these issues are, the discussion generally has ignored an element of the military commissions that profoundly shapes how national security, civil liberties, and the experience of criminal justice actually occurs: the way that lawyers charged with prosecuting and defending these cases pursue their professional duties as lawyers.

This Article considers the unique institutional identities, organizational context, ethical obligations, and professional incentives of

\footnotetext{
* Dean's Scholar and Visiting Researcher, Center on National Security and the Law, Georgetown University Law Center. My thanks to William Alford, David Cole, Peter Conti-Brown, David Glazier, Victor Hansen, Philip Heymann, David Luban, Thomas Morgan, and Stephen Vladeck for their helpful comments, and to the many lawyers involved in prosecuting and defending alleged terrorists who agreed to be interviewed for this Article.
} 
the commissions' military lawyers, analyzing how they shape and are shaped by participation in the Guantanamo Bay military commission system. This analysis is important not just as a framework for understanding the troubled history of the commissions, nor only as an interesting case study of organizational dynamics and identity theory. Rather, a close look at the institutional identities, ethical obligations, and professional incentives of the military commission lawyers reveals that the military commission system is in desperate need of reform not simply on the basis of constitutional concerns, but on the basis of legal ethics.

This Article argues that the institutional identity of the Judge Advocate General's Corps (JAG) lawyers who operate the military commission system influences these lawyers' response to the challenging ethical issues and professional pressures inherent in military commission terrorist prosecution. This analysis-based in part on interviews with JAG and civilian prosecutors and defense attorneys-documents a problem not yet addressed in the scholarly discussions of military commissions: that the commissions are structured such that JAG lawyers, a group institutionally identified with the highest standards of ethical conduct, are effectively discouraged from adhering to those standards. Although the courts-martial system in which these lawyers generally operate is not without its own ethical pressures, the unique dynamic present within the commission system effectively discourages the type of ethical conduct these lawyers have traditionally viewed as their highest priority, including zealous representation of clients and the impartial administration of justice. This Article documents the pressures faced by the commission lawyers and their causes, foremost among which is the highly politicized nature of the commission system. Recognizing and understanding how these often subtle pressures affect the military commission system is important because, taken cumulatively, these pressures increase the likelihood of conviction in ways that procedural reforms at the focus of academic, congressional, and executive debates have not addressed.

\section{Table of Contents}

INTRODUCTION

I. THE HISTORY AND STRUCTURE OF MILITARY COMMISSIONS

A. The First Guantanamo Bay Military Commission System:

Established by Military Order.

B. Congress Replaces the Bush Tribunal System with the

Military Commissions Acts of 2006 and 2009

1. Military Commissions Prosecution 
2. "Revamp": The Obama Administration and the Military Commissions Act of 2009 .

C. The Military Commission System Structure .............................. 295

1. Military Commission Judiciary ...........................................296

2. Role and Responsibilities of the Convening Authority ......299

3. Office of the Chief Prosecutor ............................................. 302

4. Office of the Chief Defense Counsel ......................................303

II. OBSTACLES TO ETHICAL COMMISSION LAWYERING ............................ 305

A. Professional Independence and JAG Institutional Identity .......... 307

B. Ethical Challenges of the Office of the Chief Prosecutor ........... 313

1. The Problem of Prosecutorial Volunteerism ........................ 314

C. Ethical Challenges in Applying the Brady Framework in the Commission System................................................................ 316

1. Professional Disincentives for Raising Ethical Challenges..................................................................... 323

D. Ethical Challenges of the Office of the Chief Defense Counsel ............................................................................... 326

1. Ethical Challenges in Operating Within a Chain of Command

2. Ethical Challenges in Military Lawyering ........................... 330

3. Professional Pressures Inherent in Guantanamo Lawyering

III. THE PATH AHEAD.

CONCLUSION 347

\section{INTRODUCTION}

The prison at Guantanamo Bay and the terrorist suspects it houses have been a lightning rod in U.S. politics, legal scholarship, and jurisprudence for the past decade. Since January 2002, when the first group of detainees arrived, lawyers have been engaged in a frequently litigious exploration of the legal problems presented by the capture, detention, and prosecution of the Guantanamo Bay detainees. Even before learning their clients' names, lawyers worked to win these detainees constitutional protection through the federal courts. In the ten years since September 11 th, these detainees have spawned multiple acts of Congress, ${ }^{1}$ a significant number of White House executive orders, ${ }^{2}$

1. See, e.g., Military Commissions Act of 2009, 10 U.S.C. $\$ 948$ a (2006 \& Supp. 2009); Supplemental Appropriations Act of 2009, Pub. L. No. 111-32, 123 Stat. 1859 (2009); Military Commissions Act of 2006, 10 U.S.C. $\S 948 \mathrm{a}$ (2006); Detainee Treatment Act of 2005,10 U.S.C. $\S 801$ (2000 \& Supp. 2005).

2. See, e.g., Exec. Order No. 13,491, 74 Fed. Reg. 16 (Jan. 27, 2009); Exec. Order No. 13,492, 74 Fed. Reg. 16 (Jan. 27, 2009); Exec. Order No. 13,493, 74 Fed. Reg. 16 (Jan. 27, 2009). 
and at least four groundbreaking U.S. Supreme Court opinions. ${ }^{3}$ Notably, the quest for a legitimate legal process to detain, prosecute, and imprison these alleged terrorists has resulted in the creation of an entirely new criminal justice system: the military commissions. ${ }^{4}$

These commissions have themselves provoked significant and prolonged debate. But that debate has centered on the commissions' (un)constitutionality, addressing such issues as the process due to alleged terrorists, the applicability of international law, and, more fundamentally, the purported trade-offs between national security and individual liberties that many suggest inhere to the commissions' structure. ${ }^{5}$ While the commissions' constitutionality and fairness remain hotly contested, ${ }^{6}$ victory must be declared, at least formally, for those who have advocated their continued existence. Congressional action has blocked detainee prosecution in federal court, and the commission system has produced seven convictions in the over eight years that it has been active. ${ }^{7}$ It now prepares to dispense justice to the "worst of the worst" among the

3. See Rasul v. Bush, 542 U.S. 466 (2004); Hamdi v. Rumsfeld, 542 U.S. 507 (2004); Hamdan v. Rumsfeld, 548 U.S. 557 (2006); Boumediene v. Bush, 553 U.S. 723 (2008).

4. The military commission system was established first by presidential fiat. See Detention, Treatment, and Trial of Certain Non-Citizens in the War against Terrorism, 66 Fed. Reg. 57,833 (Nov. 16, 2001). It was later established through congressional action. See 10 U.S.C. $\S 948$ a (2006 \& Supp. 2009).

5. See, e.g., Charlie Savage, Accused 9/11 Mastermind to Face Civilian Trial in N.Y., N.Y. Times, Nov. 13, 2009, available at http://nyti.ms/QSSi5s (covering contentious debate between ACLU and other civil liberties groups and government opponents to terrorist suspect trials in Article III courts); see also Stephen Vladeck, Terrorism Trials and the Article III Courts after Abu Ali, 88 TEX. L. REV. 1501 (2010) (using trial of Ahmed Omar Abu Ali as a case study to analyze challenges of trying terrorists in Article III courts).

6. See Stephen Vladeck, Do Military Commission Defendants Have a Sixth Amendment Right to Counsel?, LAWFARE BLOG (Dec. 29, 2011, 6:39 PM), http://bit.ly/tMjXyQ; Owen Fiss, Aberrations No More, 2010 UTAH L. REV. 1085 (2010) (noting continuation of George W. Bush's controversial, unconstitutional policies under Barack Obama); Daniel H. Benson \& Calvin Lewis, Repeal of the Military Commissions Act, 19 S. CAL. L. \& SOC. JUST. 265 (2010) (advocating repeal of the Military Commissions Act of 2009); David Glazier, Playing by the Rules: Combating Al Qaeda within the Law of War, 51 WM. \& MARY L. REV. 957 (2009).

7. See Associated Press, Guantanamo Prisoners Who Have Been Convicted, Boston.com (Feb. 28, 2012), http://bo.st/AcUCLF; Peter Finn, Guantanamo Detainee Majid Khan Pleads Guilty, Promises Cooperation, WASH. PosT, Feb. 29, 2012, available at http://wapo.st/Rv0E2C. The commissions have had several sustained periods of dormancy, most notably beginning in 2009, when President Obama ordered a halt to commission proceedings while a newly created executive task force explored whether to continue the system's use. See Exec. Order No. 13,493, 74 Fed. Reg. 16 (Jan. 27, 2009).

8. Early in 2002, then-Secretary of Defense Donald Rumsfeld referred to the detainees housed at Guantanamo Bay as "the worst of the worst," a phrase that has been blasted by detainee lawyers given the huge number of detainees ultimately released from Guantanamo by the U.S. government. See Katherine Q. Seelye, Some Guantanamo 
Guantanamo detainees, Abd al-Rahim al-Nashiri, the alleged perpetrator of the U.S.S. Cole bombing, and Khalid Sheikh Mohammed and his four alleged 9/11 co-conspirators. ${ }^{9}$ These new prosecutions-the first of which the government seeks the death penalty-will continue to highlight the controversies and questions that the commission system and its defenders have not, even now, resolved.

Those questions, however, are not simply related to constitutional or international law. Largely overlooked in the Guantanamo debate have been the significant consequences of day-to-day choices made by the lawyers operating the military commissions and the way in which ethical pressures inherent in this system, and the lawyers' perception of these pressures, influence decision-making. ${ }^{10}$ This Article builds on previous analyses and focuses on the Judge Advocate General's Corps (JAG) lawyers who have been shaping the military commission process and its outcomes in Guantanamo Bay. It analyzes the ways in which these lawyers' institutional and ethical identities influence, and are influenced by, the structure of the military commission system. A close look at the lawyers reveals that there are subtle but identifiable institutional, ethical, and professional pressures at work on the lawyers on the front lines of the Guantanamo Bay military commissions: pressures that, taken cumulatively, materially affect the allocation of justice and due process in that criminal justice system.

The commission system is not alone in producing these pressures; other criminal justice systems pose similar dilemmas. But while other systems occasionally manifest the types of pressures and incentives analyzed in this Article, particularly in terrorism-related prosecutions, the

Prisoners Will Be Freed, Rumsfeld Says, N.Y. TIMES, Oct. 23, 2002, available at http://nyti.ms/RcLuBU; Mark DenbeauX et al., Seton Hall Univ. Sch. OF L. Cent. POL'Y \& RESEARCH, RUMSFELD KNEW: DOD'S "WORST OF THE WORST" AND RECIDIVISM CLAIMS REFUTED BY RECENTLY DECLASSIFIED MEMO (2011), available at http://bit.ly/UQkbel.

9. See Charlie Savage, Accused Al-Qaeda Leader Is Arraigned in U.S.S. Cole Bombing, N.Y. TIMES, Nov. 9, 2011, available at http://nyti.ms/uib34Z; Associated Press, Khalid Sheikh Mohammed Charged in Guantánamo over 9/1I Attacks, THE GUARDIAN, June 1, 2011, available at $\mathrm{http} / / / \mathrm{bit} . l y / \mathrm{lkQB0p}$.

10. While the consequences of ethical pressures on commission lawyers has not been the subject of much scholarship to date, the Case Western Reserve Journal of International Law recently initiated a discussion of this topic at a symposium entitled "Divided Loyalties: Professional Standards and Military Duty," in which a number of speakers presented their views on whether and to what extent conflicting professional standards and military obligations have impacted the global "war on terrorism" and the military commission system in particular. See Symposium Archive, Divided Loyalties: Professional Standards and Military Duty, CASE W. RES. J. INT'L L., http://bit.ly/UFICAG. The recently published papers produced in connection with that symposium can be found in Volume 43, Number 3, of the Case Western Reserve Journal of International Law. 
commission system is unusual in the consistency and magnitude of the ethical conflicts and professional pressures placed on its lawyers. This Article documents, for the first time, the pressures faced by the various attorneys on the front lines and their causes, significant among which is the highly politicized nature of the commission system. ${ }^{11}$ Recognizing and understanding the way in which these often subtle pressures act and are acted upon in the military commission system is important because, taken cumulatively, these pressures increase the likelihood of conviction in ways that procedural reforms at the focus of the current academic, congressional, and executive debates have not addressed.

In describing the ways in which legal ethics and lawyer identities influence the operation of the military commissions, this Article focuses on the institutional identity of JAG prosecutors and defense counsel, and traces how this identity has conditioned counsel's response to the ethical challenges and professional pressures inherent in lawyering in the military commission system. The JAG Corps has established a tradition of high ethical conduct and respect for the rule of law. As a result, in the early years of the military commission system, when political forces overtly operated in the commissions to ensure conviction of the Guantanamo detainees on trial, JAG lawyers committed to this institutional identity were considered whistleblowers. In the case of multiple JAG commission prosecutors, this meant resigning from their posts. In the case of the majority of JAG defense counsel, this meant engaging in an assault on the commission system's legitimacy, notwithstanding professional disincentives against doing so. Although the Obama Administration and Chief Prosecutor Brigadier General Mark Martins have attempted to distance the commission system from its troubled history ${ }^{12}$ - and, indeed, many scholars believe that Obama's

11. This Article is the first to analyze the ethical conflicts and professional pressures faced by lawyers across the commission system and to consider the consequences of these challenges for the legitimacy of the military commission process. It is not, however, the first to observe that commission defense counsel face unique ethical challenges. An increasing number of scholars, many of them practitioners before the commissions or habeas courts, have presented the compelling narrative of counsel for the Guantanamo Bay detainees. See, e.g., David J. R. Frakt, The Practice of Criminal Law in the Guantanamo Military Commissions, 67 A.F. L. REV. 35 (2011); Alexandra D. Lahav, Portraits of Resistance: Lawyer Responses to Unjust Proceedings, 57 UCLA L. REV. 725 (2010); Matthew Ivey, Challenges Presented to Military Lawyers Representing Detainees in the War on Terrorism, 66 N.Y.U. ANN. SURV. AM. L. 211 (2010); Peter Margulies, The Detainees' Dilemma: The Virtues and Vices of Advocacy Strategies in the War on Terror, 57 BufF. L. REV. 347 (2009); David Luban, Lawfare and Legal Ethics in Guantanamo, 60 STAN. L. REV. 1981, 1990 (2008).

12. See Dina Temple-Raston, Justice Department Lawyers Play Role in Guantanamo, NPR (Feb. 3, 2012), available at http://n.pr/zBp7jZ (observing that Mark Martins "has been called Guantanamo's detox man . . . because his mission is to provide legitimacy to a military commission system that until recently was seen as extremely 
2009 statutory reforms to the commission system did improve the constitutionality and legality of that criminal justice regime ${ }^{13}$-the troubled history of the commission system remains part of the system today. Despite extensive procedural revision of the military commission system, the organization and structure of the system have remained untouched by the 2009 "revamp" of the commission system. The statutory improvements have also failed to remove the taint associated with the military commissions' politicized past and history of detainee mistreatment. ${ }^{14}$ As a result, notwithstanding the presence of a more open and transparent commission leadership, ${ }^{15}$ JAG lawyers operating within the system are well aware that the commission system remains vulnerable to behind-the-scenes political manipulation.

This Article will proceed in three parts. Part I will provide the legal and historical context necessary to understand the role lawyers play in the Guantanamo Bay commissions and the commissions' unique organizational dynamic. The history of the commissions are important because they illustrate the types of ethical challenges faced by military commission lawyers and the structural and institutional origins of these challenges, the majority of which have not been altered by statutory revisions to these military commissions.

Part II will frame a unique and endemic problem of professional independence in the military commission system. The commissions' structure and politicization have created a toxic environment for principled lawyering. Part II will first explore some of the obstacles to professional independence inherent in the military commission structure and the ways in which the open politicization of the process in particular has conflicted with the strong institutional tradition of independence and rule-of-law among the JAG Corps. This analysis will reveal that multiple factors-including the lack of clarity in commission law, the

toxic."); see also Morris Davis, Guantanamo's Deepening Failure, SALON.COM (Feb. 7, 2012, 11:00 AM), http://bit.ly/z5ph7c (noting Mark Martins's repeated use of the phrase "reformed military commissions" and opining that its use aimed to the commissions from past failures).

13. See, e.g., Scott L. Silliman, Prosecuting Alleged Terrorists by Military Commission: A Prudent Option, 42 CASE W. Res. J. InT'L L. 289, 295 (2009); John D. Altenburg, Jr., Remarks on "The Law of Counterterrorism," Georgetown University Law Center (Feb. 2, 2011) (observing that the most notable difference between the military commission system and courts-martial system is the admissibility of hearsay, and that this alteration is appropriate and necessary for prosecuting law of war violations).

14. See Andrea Prasow, Hidden Torture: Behind the Plea Bargain of Majid Khan, JURIST (Mar. 2, 2012), http://bit.ly/zRAhjt (observing that the military commission system aims to keep the tortured past of GTMO detainees buried).

15. See MIL. COMM'Ns, http://bit.ly/qoWOZj (last visited Oct. 9, 2012) (the military commission's mission is to "[p]rovide fair and transparent trials of those persons subject to trial by Military Commissions while protecting national security interests"). 
specter (or reality) of political manipulation, and professional disincentives to ethically conscientious lawyering-impact the choices made by JAG counsel. These factors will also show that conviction is more likely in military commissions than it would be in Article III or courts-martial proceedings, which calls into question the legitimacy of the commission system.

Part III will explore the path ahead for the military commission system. Building on the conclusions of Part II, this Part will advocate for commission system reform to mitigate the fundamental legal-political tensions that have plagued it to date. As long as the system is structured such that all commission lawyers fall within the direct influence of the Convening Authority-that is, the political appointee administrator of the commission system-and the Convening Authority falls within the direct political control of the President, these insolubility problems will persist. Accordingly, Part III will advocate for reforming the system to facilitate defense counsel autonomy, increasing institutional protections for military judges, and requiring more public accountability for the Convening Authority.

The prosecution of alleged terrorists presents a host of thorny legal, moral, and political challenges, and many of these challenges would apply in any forum in which terrorist suspects are tried. Given the nature of these cases, the national security issues at stake, and the visceral reactions many Americans feel toward terrorism allegations, there may be no perfect forum for trying terrorists. Nevertheless, the lesson learned from lawyers at Guantanamo Bay is that military commissions amplify ethical challenges in a way that does not occur in the federal courts or courts-martial. Because these challenges result in a justice system slanted toward conviction, a close look at the lawyering on the ground in Guantanamo Bay points toward the need for significant reform to the commission system.

\section{THE HISTORY AND STRUCTURE OF MILITARY COMMISSIONS}

In the wake of the September 11 th attacks, President George W. Bush initiated a campaign to capture and detain individuals who had facilitated that assault on the United States and who otherwise had an interest in harming the United States through terrorist tactics. Those detained would later be housed at a small naval base in Guantanamo Bay, Cuba (GTMO) and would be tried by a military tribunal system specially designed for prosecuting terrorists and punishing violations of the law of war. ${ }^{16}$ Because the tribunal system-later called the "military

16. Mil. Order of Nov. 16, 2001 -Detention, Treatment, and Trial of Certain NonCitizens in the War against Terrorism, 66 Fed. Reg. 57,831-36 (Nov. 16, 2001). 
commission system"-offered far fewer protections than those found in the U.S. criminal court system or the military's courts-martial system, it was immediately controversial among legal academics and civil liberties groups. ${ }^{17}$ Its early history, marked by mass resignations among commission prosecutors and by allegations that the legal process was being used as a vehicle for political expedience, only heightened the controversy.

\section{A. The First Guantanamo Bay Military Commission System: Established by Military Order}

Although the military commission system was established in 2001, the first charges were not issued until February $2004 .^{18}$ Initially, the commission proceedings were conducted largely in secret; however, such secrecy, in addition to abbreviated due process protections, quickly led to allegations that the commissions were designed only to convict suspected terrorists. ${ }^{19}$ These criticisms were fueled by the 2004 resignation of four JAG lawyers from the Office of Chief Prosecutor, all of whom alleged that the then-Chief Prosecutor of the military commission system, Fred Borch, had openly acknowledged that the commission trials were a rubber stamp process. According to these prosecutors, Borch called a meeting of his prosecutorial team to inform them that they did not need to worry about acquittals because the commission panel would be "handpicked." ${ }^{20}$ He further suggested that the prosecutors need only concern themselves with building a record for the review panel and for "review by academicians 10 years from now." 21 Questions had already been swirling about the legitimacy of the military commission system, ${ }^{22}$ and this controversy bolstered the widely held view that the commission system was designed not to dispense justice, but to convict without due

17. See, e.g., Curtis A. Bradley \& Jack L. Goldsmith, The Constitutional Validity of Military Commissions, 5 GREEN BAG 2D 249 (2002) (arguing in favor of constitutional authority to conduct military commission trials); Neal K. Katyal \& Laurence H. Tribe, Waging War, Deciding Guilt: Trying the Military Tribunals, 111 YALE L.J. 1259 (2002) (arguing against such authority).

18. Frederic L. Kirgis, United States Charges and Proceedings Against Two Guantanamo Detainees for Conspiracy to Commit Crimes Associated with Armed Conflict, ASIL INSIGHTS (Mar. 2004), available at http://bit.ly/VYTszH.

19. See, e.g., Kevin J. Barry, Military Commissions: Trying American Justice, ARMY LAW., at 1 (Nov. 2003); Frank Davies, Military Lawyer: Terror Trials 'Unfair,' MIAMI HERALD, Jan. 22, 2004, at Al (quoting commission defense counsel that military commission system was "designed to produce guilty verdicts"); see also Editorial, First Steps at Guantanamo, N.Y. TIMES, Jan. 21, 2009, available at http://nyti.ms/dlgmTK (noting that former commission prosecutors have called the system "rigged").

20. John Carr, A Few Good Men, 311 HARPER's BAZAAR 23 (2005).

21. Id.

22. See, e.g., Katyal \& Tribe, supra note 17. 
process. After the Supreme Court invalidated the commission system in 2006 in Hamdan v. Rumsfeld, ${ }^{23}$ the Bush Administration had limited options. It consequently turned to Congress for enabling legislation.

\section{B. Congress Replaces the Bush Tribunal System with the Military Commissions Acts of 2006 and 2009}

On September 6, 2006, President Bush announced that Khalid Sheikh Mohammed, other alleged engineers of the 9/11 attacks, and eleven other "high value" terrorist suspects had been transferred to GTMO from CIA black sites abroad and would be prosecuted by military commission as soon as Congress acted to authorize the process. ${ }^{24}$ The transfer of these "high value detainees" to Guantanamo Bay spurred Congress to speedy action. ${ }^{25}$ Less than four months after the Supreme Court handed down its Hamdan opinion, Congress passed the Military Commissions Act of 2006 ("2006 MCA"), authorizing use of military commissions and establishing procedural rules modeled upon, but departing in some significant ways from, the Uniform Code of Military Justice (UCMJ) that governs the military's courts-martial system. ${ }^{26}$ The JAG commission lawyers returned to work in earnest.

\section{Military Commissions Prosecution}

As the military commissions moved ahead, controversy continued to plague the system. In May 2008, multiple military commission judges barred the Convening Authority's Legal Advisor, Brigadier General Thomas W. Hartmann, from having further involvement with multiple pending military commissions. ${ }^{27}$ This action came eight months after the Chief Prosecutor for the commissions, Colonel Morris Davis, filed a formal complaint alleging that Hartmann had unlawfully attempted to influence commission prosecutors - a complaint over which Davis ultimately resigned. ${ }^{28}$ Davis alleged that Hartmann had pressured him to

23. Hamdan v. Rumsfeld, 548 U.S. 557, 561 (2006).

24. Press Release, President George W. Bush, President Discusses Creation of Military Commissions to Try Suspected Terrorists (Sept. 6, 2006), available at $\mathrm{http}: / / 1$.usa.gov/kxXFXC.

25. See Morris D. Davis, Historical Perspective on Guantanamo Bay: The Arrival of the High Value Detainees, 42 CASE W. RES. J. INT'L L. 115, 119 (2009).

26. The significance of these divergences will be discussed infra Part I.C; see also JenNifer K. Elsea, Cong. Research Serv., RL 33688, The Military Commissions ACt of 2006: Analysis of Procedural Rules and Comparison with Previous DOD RULES AND THE UNIFORM CODE OF MILITARY JUSTICE, at CRS-1 (2007).

27. Carol Rosenberg, Judge Bars Pentagon Official from Guantanamo Prosecution, Miami HERALD, May 10, 2008, available at http://bit.ly/W1 r8MU.

28. See William Glaberson, War-Crimes Prosecutor Quits in Pentagon Clash, N.Y. TIMES, Oct. 6, 2007, available at http://nyti.ms/T57WcA. 
bring charges in specific cases, in violation of the prosecutorial independence provided Davis under the $2006 \mathrm{MCA}$ (a departure from the courts-martial system). ${ }^{29}$ Davis contended that Hartmann's conduct amounted to "unlawful command influence," an attempt by a senior officer to overbear a lawyer's independent exercise of discretion (conduct strictly prohibited by both the UCMJ and the $2006 \mathrm{MCA}$ ). ${ }^{30}$ In Hartmann's case, three commission judges held that he had overstepped his role as Legal Advisor to the Convening Authority, although they stopped short of finding him guilty of unlawful command influence. ${ }^{31}$

During this time, allegations also surfaced regarding then-Defense Department General Counsel William J. Haynes II. Morris Davis reported that Haynes had attended his hiring interview, in which Hartmann had instructed Davis on which cases to prosecute first. ${ }^{32}$ Hartmann had suggested Davis focus his efforts on "sexy" cases with "blood on them" for political reasons (namely to garner public support in advance of an election year). ${ }^{33}$ Davis, during that same meeting, referenced the likelihood of some acquittals in the commission system, and recalled that Haynes's eyes went wide as he responded, "We can't have acquittals [at Guantanamo]. If we've been holding these guys for so long, how can we explain letting them get off? We've got to have convictions." Haynes tendered his resignation shortly after Davis made the conversation public. ${ }^{35}$ Davis later testified that other senior Pentagon officials, including Deputy Defense Secretary Gordon England, also made it clear to him that charging some of the highest-profile detainees before elections that year could have "strategic political value," and urged him to take that course. ${ }^{36}$ Davis later provided similar testimony to Congress.

29. See id.; see also Rosenberg, supra note 27.

30. See Glaberson, supra note 28; Rosenberg, supra note 27.

31. See Adam Zagorin, Trying to Tie Obama's Hands on Gitmo, TIME, Dec. 8, 2008, available at http://ti.me/4pabM3. As a result, Hartmann was restricted from further influencing the three specific cases from which he had been barred, but he continued operating in a logistical role in the commissions following the rulings and prior to his retirement from the Air Force. See generally Carol Rosenberg, 'War Court Czar' Wants to Retire, MCCLATCHY NEWs, Nov. 2, 2008, available at http://bit.ly/W3tniN (reporting Hartmann's request to retire from the Air Force in February 2009).

32. See Adam Zagorin, Gitmo's Courtroom Wrangling Begins, Time, Apr. 25, 2008, available at http://ti.me/8KUuzb; see also Interview with Morris Davis, Former Chief Prosecutor, Office of Mil. Comm'ns, in Washington, D.C. (Apr. 13, 2012) [hereinafter Morris Davis Interview].

33. Id.; see also Morris Davis Interview, supra note 32.

34. Zagorin, supra note 32.

35. See Pet. for Writ of Mandamus and Writ of Prohibition at 19-20, In re Al Shibh, No. 09-1238 (D.C. Cir. Sept. 9, 2009).

36. Josh White, From Chief Prosecutor to Critic at Guantanamo Bay, WASH. PosT, Apr. 29, 2008, available at http://wapo.st/Rgflny. 
Under the Bush Administration, 28 detainees were charged, 14 were referred to trial, and, ultimately, 3 detainees were convicted and sentenced. ${ }^{37}$ The majority of Guantanamo detainees were released from detention without resort to the military commission process. The U.S. government initiated transfer out of GTMO for many of the detainees, while others secured release by successfully petitioning the D.C. District Court for writs of habeas corpus. ${ }^{38}$

2. "Revamp": The Obama Administration and the Military Commissions Act of 2009

On January 22, 2009, one day after his inauguration as President of the United States, President Barack Obama issued three executive orders initiating widespread policy reform with regard to Guantanamo Bay. ${ }^{39}$ Ongoing military commissions were essentially halted while multiple task forces reviewed options for closing the detention facility and processing the remaining detainees. ${ }^{40}$ On May 15, 2009, President

37. Edward F. Sherman, Terrorist Detainee Policies: Can the Constitutional and National Law Principles of the Boumediene Precedents Survive Political Pressures?, 19 TUL. J. INT'L \& COMP. L. 207, 243 (2010). Australian detainee David Matthew Hicks pled guilty to one charge of providing material support to terrorism in March 2007. See Press Release, DOD, Detainee Convicted of Terrorism Charge at Guantanamo Trial (Mar. 30, 2007), available at http://1.usa.gov/VRvsQu. Yemeni detainee Ali Hamza Ahmad Suliman al Bahlul boycotted his commission proceeding, but was tried and convicted of conspiracy and providing material support to terrorism on November 3, 2008. See Press Release, DOD, Detainee Convicted of Terrorism Charge at Guantanamo Trial (Nov. 3, 2008), available at http://1.usa.gov/QSZkss; David Mcfadden, At Gitmo: Life Sentence for Bin Laden Propagandist, USA TODAY, Nov. 4, 2008, available http://usat.ly/RggOQ4. On August 8, 2008, Hamdan was acquitted of conspiring in terrorist attacks but was convicted of providing material support to terrorism and was sentenced to 5.5 years in prison, an effective sentence of six months of detention given the time he had already served. Jerry Markon, Hamdan Guilty of Terror Support, WASH. PosT, Aug. 7, 2008, available at http://wapo.st/W3A84p.

38. After spending years awaiting a hearing before the commissions, recourse to habeas corpus also meant freedom for several commission defendants, including Mohammed Jawad and Fouad Mahmoud al Rabiah. See David J.R. Frakt, Mohammed Jowad and the Military Commissions of Guantánamo, 60 DUKE L.J. 1367 (2011).

39. Exec. Order No. 13,491, 74 Fed. Reg. 16 (Jan. 27, 2009) (making major changes in interrogation procedures available to the CIA and other government agencies and creating a "Special Task Force on Interrogation and Transfer Policies" to conduct a systematic review of current interrogation and transfer policies); Exec. Order No. 13,492, 74 Fed. Reg. 16 (Jan. 27, 2009) (ordering closure of GTMO detention facility and setting up a task force to review the status of each individual detained at GTMO to determine whether and how the release or transfer of each detainee was possible); Exec. Order No. 13,493, 74 Fed. Reg. 16 (Jan. 27, 2009) (creating the Detention Policy Task Force, charged with identifying lawful options for the disposition of individuals captured or apprehended in connection with armed conflicts or counterterrorism operations).

40. JeNNIFER K. ElSEA, CONG. RESEARCH SERV., R40932, COMPARISON OF RightS IN Miltary Commission Trials and Trials IN Federal Criminal Court, at CRS-2 (2012). 
Obama announced that he would be revamping but continuing the military commission process, though he made clear that he intended to use Article III courts as the primary forum for detainee prosecution. ${ }^{41}$ Congress was obliging. The statutory "revamp" left the commission system structurally the same as the tribunal system that the Bush Administration created; however, the "revamp" expanded appellate review and built on other $2006 \mathrm{MCA}$ protections granted to detainees on trial. Reforms included a ban on evidence obtained by "cruel, inhuman, or degrading treatment," a shift in the burden of proof on hearsay evidence to the prosecution, and a new provision for appointment and funding of "learned counsel" to assist defense counsel in capital cases. ${ }^{42}$ With the new statute in place, commission prosecutions moved forward again, resulting in four guilty pleas between July 2010 and the present. ${ }^{43}$

\section{The Military Commission System Structure}

The military commission system is similar to the courts-martial system in structure, but differs in significant ways. The majority of courts-martial proceedings involve offenses such as barracks theft, child pornography, or absence without leave from an assigned post that typically do not involve substantial motions practice, voir dire, legal research, or handling of classified information. ${ }^{44}$ Capital cases are incredibly rare in the courts-martial system. ${ }^{45}$ Commission proceedings, on the other hand, require a very different base of knowledge and experience than do standard courts-martial cases. Commission cases are rife with international law, constitutional law, and law of war complexities; require extensive legal research and brief writing; involve

41. Michael D. Shear \& Peter Finn, Obama to Revamp Military Tribunals, WASH. Post, May 16, 2009, available at http://wapo.st/DTtZx.

42. 10 U.S.C. $§ 949 a$ (b)(2)(C)(ii) (2006 \& Supp. 2011).

43. Sudanese Ahmed Mahmoud al Qosi pled guilty in July 2010, Canadian Omar Khadr pled guilty in August 2010, Sudanese Noor Uthman Muhammed pled guilty in February 2011, and Pakistani native/former Baltimore resident Majid Khan pled guilty in February 2012. See Associated Press, Guantanamo Prisoners Who Have Been Convicted, The SeATTLE Times, Feb. 28, 2012, available at http://bit.ly/OUL7wU; Peter Finn, Guantanamo Detainee Majid Khan Pleads Guilty, Promises Cooperation, WASH. PosT, Feb. 29, 2012, available at http://wapo.st/Rv0E2C.

44. Telephone interview with Military Commission Defense Counsel (Sept. 2, 2011) [hereinafter Mil. Comm'n Interview 9/2].

45. Between 1984 and 2011 , there were 52 known capital courts-martial proceedings, resulting in 16 death sentences, 10 of which were later commuted or reversed. See Dwight Sullivan, Updated Military Death Penalty Statistics, NAT'L INST. OF MiL. JUST. BLOG-CAAFLOG (May 30, 2011), http://bit.ly/nEVV8B. By way of comparison, in a far shorter period, 1995-2001, federal prosecutors sought the death penalty in approximately 159 cases. U.S. DEP'T OF JUST., THE FEDERAL DEATH PENALTY SYSTEM: SUPPlementary Data, ANALYSIS AND Revised Protocols for CaPITAL CASE REVIEW n. 17 (June 6, 2011), available at http://1.usa.gov/quByNL. 
novel legal and procedural theories; and, unlike courts-martial cases, generally drag on for years. The commission system also lacks a clear body of binding precedent. Under the 2009 MCA, courts-martial precedent is persuasive in commission court, but not binding, and no mention is made of Article III precedent. ${ }^{46}$ As a result, both military judges and trial lawyers have faced a steep learning curve in navigating this new forum. This learning curve has been made even more difficult by extended periods without the guidance of any rules of evidence or procedure,${ }^{47}$ as well as the expectedly ad hoc complications of a newlyestablished criminal justice facility and administrative body. ${ }^{48}$

\section{Military Commission Judiciary}

Commission judges preside over trials in the same way as federal and courts-martial judges, but they operate in a far more opaque and politicized environment. Like a federal judge, a military commission judge oversees selection of a jury, or a "commission panel," as the jury equivalent is called in the military commission system. Unlike the random "jury wheel" that summons individuals for federal jury duty from local voting rolls, but much like the courts-martial process, the commission convening authority handpicks potential commission jurors. Under the $2009 \mathrm{MCA}$, the convening authority is to detail jurors it determines "are best qualified for the duty by reason of age, education, training, experience, length of service, and judicial temperament." ${ }^{49}$ The opaque criteria applied by the convening authority in selecting commission members and the lack of statutory selection criteria led some to speculate that the commissions are or may be subject to official manipulation. ${ }^{50}$ This concern was amplified by early suggestions that the

46. See 10 U.S.C. $\S 948$ b(c) (2006 \& Supp. 2009) (explaining that, while military commission procedure is based on UCMJ procedure, the "judicial construction and application" of the UCMJ are not binding on military commissions, a provision which has the effect that neither Article III precedent nor UCMJ precedent are binding in the military commission system).

47. See, e.g., Nat'l INSt. Mil. Just., NimJ Reports from Guantanamo Volume III, at 4, 8 (2010), available at http://bit.ly/QedfI2 (describing the lack of a military commission manual or rules as of April 2010, six months after passage of the 2009 Military Commissions Act).

48. These complications have ranged from intermittently operating courtroom microphones to failures in real-time translation to the courtroom lights turning out in the middle of hearings. Telephone Interview with Military Commission Defense Counsel (Sept. 7, 2011) [hereinafter Mil. Comm'n Interview 9/7].

49. 10 U.S.C. $\S 948 i(b)$ (2006 \& Supp. 2009).

50. Sharon Kelly, Report from Guantanamo: Al-Bahlul Case Shows Trials Should Be Held in Federal Courts, JURIST, Nov. 1, 2008, available at http://bit.ly/PoLgIO; David McFadden, Bin Laden Aide Boycotts His Own Guantanamo War Crimes Trial with Lawyer, HufFINGTON POST (Oct. 27, 2008, 8:28 PM), http://huff.to/RxYe3r. 
panels would be hand-picked by the convening authority ${ }^{51}$ and by JAG lawyers' experience with jury selection in the military commission system.

Australian David Hicks's case was the first to make news on the jury selection issue in 2004, when three seated panel members were removed by then-Convening Authority John Altenburg in response to outcries from defense lawyers and human rights groups. ${ }^{52}$ Through voir dire in the Khadr case in 2008, defense counsel discovered that all of the Air Force officers on the panel had specifically volunteered to serve on the commission panel, ${ }^{53}$ raising serious questions about their impartiality. ${ }^{54}$ During the Hamdan voir dire, defense counsel learned that one member of the commission panel was a former Academy roommate of the commander of the U.S.S. Cole,$^{55}$ a fact only discovered through an incredibly detailed voir dire questionnaire (the use of which is, as in federal court, completely at the discretion of the commission judge, not typical to courts-martial, and not used in other commission panel selections). ${ }^{56}$ In another case, a commission judge refused to dismiss from the panel a juror whose former Air Force co-pilot had been a victim of the $9 / 11$ attacks, despite protestations of bias made by defense counsel. ${ }^{57}$ The commission panel selection process is as opaque today as it was in 2004 when the first panel was convened, leaving the system vulnerable to and subject to suspicions regarding political meddling in the jury pool.

51. See supra Part I.A (discussing a meeting in which Chief Prosecutor Fred Borch informed prosecutors that they did not need to worry about acquittals because commission panels would be "handpicked").

52. Andrew Buncombe, Three 'Judges' Removed Due to Pentagon Bias, THE INDEPENDENT (UK), Oct. 23, 2004, http://ind.pn/RjJm8i. Among the panel members removed was an officer who had overseen an operation that transferred suspected terrorists from Afghanistan to Guantanamo Bay, another was an intelligence officer in Iraq, and the third caused controversy when he said he did not know the details of the Geneva Conventions. Id.

53. Frakt, supra note 11 , at 82 (citing an interview with U.S. Army Lt. Col. Jon Jackson in August 2010). But see Morris Davis Interview, supra note 32 (noting that this is actually consistent with Air Force standard practice, in which officers who are known to be available are solicited to be panel members and asked to respond voluntarily).

54. Buncombe, supra note 52 (defense counsel successfully challenged each of these panel members for cause); see also Mot. to Disqualify All United States Air Force Members Due to Improper Panel Selection, United States v. Khadr, 717 F. Supp. 2d 1215 (Ct. Mil. Comm'n Rev. 2007), available at http://bit.ly/uNGVzH.

55. The U.S.S. Cole was a Navy destroyer bombed by al Qaeda on October 12, 2000, while the ship was refueling in Aden Harbor, Yemen. The attack resulted in the loss of 17 sailors and a 40-by-60 foot hole in the ship. See U.S.S. Cole Memorial, U.S. NAVY, http://bit.ly/auaL14 (last visited Oct. 10, 2012).

56. Mil. Comm'n Interview 9/2, supra note 44.

57. Telephone interview with Military Commission Defense Counsel (Sept. 13, 2011) [hereinafter Mil. Comm'n Interview 9/13]. 
The high number of problematic commission panel members is particularly troubling given that the number of available members to choose from is, in keeping with the courts-martial tradition, incredibly small. The limited pool raises questions about whether the commission system is capable of empaneling a truly impartial death-qualified jury. ${ }^{58}$ In the trial of Zacarias Moussaoui, the alleged "20th hijacker" of the September 11th attacks, ${ }^{59}$ which was held in federal court in the Eastern District of Virginia, the 16 jurors who heard the case were selected from a panel of 900 potential jurors. ${ }^{60}$ Likewise, in capital cases on the state level, it is not uncommon for the number of potential jurors to be in the 800 s range ${ }^{61}$ By contrast, only 20 officers comprised the original commission panel convened to try the alleged $9 / 11$ co-conspirators. ${ }^{62}$ Given the logistical challenges already involved in detailing members of the military to extended service in Guantanamo Bay for jury duty, gathering 800 servicemen to empanel a jury comparable to that available in the federal court system is simply not practical: a real problem in a case where the death penalty is at stake.

Military commission judges also lack the authority that their federal and UCMJ counterparts exercise over classified information. This distinction is important given the volume of classified information involved in commission prosecutions. Regarding classification, the 2009 MCA incorporates portions of the Classified Information Procedures Act (CIPA)-the classification statute applicable in federal and UCMJ courts-but sends the very different message that protection of classified information, not the rights of the accused, should be the judge's top

58. Capital cases complicate jury selection, as the judge must impanel not only an impartial jury but also one in which each member would be willing to impose the death penalty should the evidence call for it. Many commentators, and the U.S. Supreme Court, have acknowledged that excluding non-death-qualified jurors may produce juries "somewhat more 'conviction-prone' than 'non-death-qualified." John Quigley, Criminal Law and Human Rights: Implications of the United States Ramification of the International Covenant on Civil and Political Rights, 6 HARV. HUM. RTS. J. 59, 79-80 (1993) (quoting Lockhart v. McCree, 476 U.S. 162, 173 (1986)).

59. Jessica Reaves, The Case against Zacarias Moussaoui, TIME, Jan. 2, 2002, available at http://ti.me/4oliyZ. Subsequent information obtained from Ramzi bin AlShibh, alleged to be the financier of the $9 / 11$ attacks, indicates that Moussaoui was originally to play a role in the $9 / 11$ plot but ultimately was rejected due to concerns with his reliability. See Viveca Novak, How the Moussaoui Case Crumbled, TrME, Oct. 19, 2003, available at $\mathrm{http}: / / \mathrm{ti}$.me/TDKxEu.

60. Telephone interview with Military Commission Defense Counsel (Sept. 9, 2011) [hereinafter Mil. Comm'n Interview 9/9].

61. See, e.g., Cal. Comm'N on the Fair Admin. of Justice, Final Report and Recommendations on the administration of the Death Penalty in California 72 (2008) ("In Los Angeles County, 800 potential jurors may be summoned for a death penalty case.").

62. Mil. Comm'n Interview 9/9, supra note 60. 
priority. CIPA permits a judge to order disclosure of classified information, requiring only that the judge consider whether alternate evidence (such as a summary or affidavit) could be used in place of that evidence. By contrast, under the 2009 MCA, a military judge "shall not" order disclosure of classified information. ${ }^{63}$ Instead, the military judge merely serves a role in reviewing and ensuring the fairness of the alternate evidence presented. ${ }^{64}$ Likewise, the MCA "requires" military judges to permit the government to introduce admissible evidence without disclosing the "sources, methods, or activities by which the United States acquired the evidence," provided the military judge finds that such information is classified and that the evidence is reliable. ${ }^{65}$ The military judge may require the government to present an unclassified summary of that source/methods information if it is "consistent with national security," but the MCA makes clear that the judge "need not" do so. ${ }^{66}$

In other words, although there are similarities in the rules governing UCMJ, Article III, and commission courts, the unique message the 2009 MCA sends to military judges, prosecutors, and defense counsel is that, in the commission forum, the government determines what evidence is classified (and therefore determines what evidence must be produced), and all other parties must defer to that determination. Given the volume of classified evidence involved in a commission proceeding, this distinction creates not only a distinct advantage for the government in commission court, it makes a real difference in how prosecutors and defense counsel perceive the fairness of the commission system and operate within that system.

\section{Role and Responsibilities of the Convening Authority}

The convening authority plays a central role in both the UCMJ and military commission systems, serving as the administrator and supervising judge of both systems. While the role and authority of the convening authority may be similar on paper, in practice, the convening

63. Compare 10 U.S.C. $\$ 949$ p-1(a) (2006 \& Supp. 2009) ("Under no circumstances may a military judge order the release of classified information to any person not authorized to receive such information"), with 18 U.S.C. app. 3 \& (2006) ("The court, upon a sufficient showing, may authorize the United States to delete specified items of classified information from documents to be made available to the defendant through discovery under the Federal Rules of Criminal Procedure, to substitute a summary of the information for such classified documents, or to substitute a statement admitting relevant facts that the classified information would tend to prove."), and 10 U.S.C. \$ 949p-6(f)(3) (2006 \& Supp. 2009).

64. See generally 10 U.S.C. $\S 949$ p-6(d)-(g) (2006 \& Supp. 2009).

65. 10 U.S.C. $\$ 949 f(3)$ (2006 \& Supp. 2009).

66. Id. 
authority operates quite differently in the commission system. The military commission convening authority has a distinct political component that is not seen in courts-martial. The military commission convening authority is appointed by the Secretary of Defense to serve in that position indefinitely and operates under the direct control of the Secretary, reporting directly to the DOD General Counsel. ${ }^{67}$

In courts-martial, the convening authority is a military officer who does not serve in that role on a permanent basis, who has not been appointed to that role by the DOD's political leadership, and who operates largely within the military DOD hierarchy, as opposed to reporting to the DOD General Counsel. ${ }^{68}$ Instead, convening authorities typically are senior officers who have risen through the ranks-base commanders, for instance-and who serve as convening authorities when circumstances (namely, criminal action on-base) require it. The courts-martial system also serves a very different purpose, aimed at maintaining troop discipline and reinforcing respect for command authority ${ }^{69}$ as a result, a UCMJ convening authority typically enjoys "the presumption of unbiased and apolitical decision-making that accompanies the role of a military commander."

By making the military commission convening authority a political appointee, Congress created a structure very different from the courtsmartial system: one subject to political influence and expediency in a way that the courts-martial system is not. ${ }^{71}$ This distinction was immediately perceived by JAG lawyers accustomed to operating under a UCMJ convening authority, and the significance of it was reinforced by the attempts to exert political influence over the system that followed. This overt insertion of political forces into the traditional UCMJ structure influences the perceptions and decision-making of JAG prosecutors and defense counsel in the military commission system, as will be discussed infra.

67. See DOD, Regulation for TRIAL by Military Commissions 3 (2007)

68. Gregory S. McNeal, Organizational Culture, Professional Ethics and Guantanamo, 42 CASE W. RES. J. INT'L L. 125, 130-31 (2009).

69. See Note, Prosecutorial Power and the Legitimacy of the Military Justice System, 123 HARV. L. REV. 937, 939-40 (2010) ("Historically, the maintenance of discipline as a means of reinforcing the military's combat function was the primary purpose of military justice. Since the discipline of the troops was primarily the responsibility of the commander, the military justice system was seen as a tool of the commander to enforce his authority over his subordinates. As a result, the commander historically had virtually unchecked control over military justice.").

70. See McNeal, supra note 68.

71. See Gregory S. McNeal, Beyond Guantanamo, Obstacles and Options, $103 \mathrm{Nw}$. UNIV. L. Rev. ColloQuY 29, 34 (2008) (noting that ability of Secretary of Defense to appoint a civilian political appointee as Convening Authority was "a substantial departure from courts-martial practice") 
Unlike the courts-martial system, in which the convening authority directs and is advised by the prosecution, the military commission system created an Office of Chief Prosecutor intended to operate independently from the convening authority - an innovation which has caused some confusion. JAG lawyers are accustomed to the unitary model employed in the UCMJ system, and the operational distinctions between that system and the commissions are difficult to detect: the convening authority (and its influential second-in-command, the legal advisor) is expected to supervise and work closely with the chief prosecutor, making the lines between advice from the convening authority and attempts by the convening authority to exert "unlawful command influence" over the prosecutor's office difficult to distinguish. $^{72}$ The blurry distinction between the UCMJ system and the commissions has been exacerbated by the fact that, in the commissions' past, its convening authority and legal advisor have attempted to directly influence the chief prosecutor, with no significant condemnation of such activity even after a full DOD investigation. ${ }^{73}$ As a result, commission prosecutors accustomed to the military justice system find themselves in some respects navigating new waters in the military commissions.

As others have suggested, by vesting the commissions' convening authority "with all the power found in military commanders but without the attendant command responsibility justification. ... Congress allowed for the creation of a politically-motivated organizational culture from what should be an apolitical organization culture." ${ }^{, 74}$ The commission convening authority, the military commission judges, the prosecutors, and the defense counsel all operate under the direction of the same authority, the Secretary of Defense, just as they do in the UCMJ system. Unlike the UCMJ system, however, the military commission system uses political forces to appoint its convening authority directly, and that convening authority reports directly back to these political entities. Allowing direct political influence over a criminal justice system raises questions about the legitimacy and fairness of the system. Moreover, for JAG officers accustomed to operating in the rule-of-law-bound, apolitical courts-martial, ${ }^{75}$ the open presence of political forces raises a

72. See generally McNeal, supra note 68 .

73. Although there was an official inquiry following Morris Davis's formal complaint regarding Brigadier General Hartmann's conduct, the official response to his complaint was a memorandum reiterating that Davis was beneath Hartmann in the chain of command, receipt of which prompted his resignation. See Col. Morris Davis, Applying the Law in Guantanamo: "The Government's Narrative Was a Lie," SPIEGEL, May 2, 2011, http://bit.ly/lmm9si.

74. McNeal, supra note 68, at 132.

75. See Ori Aronson, Out of Many: Military Commissions, Religious Tribunals, and the Democratic Virtues of Court Specialization, 51 VA. J. INT'L L. 231, 277 (2011) 
host of ethical pressures beyond those usually encountered in the courtsmartial system.

\section{Office of the Chief Prosecutor}

In June 2011, the DOD announced that U.S. Army Brigadier General Mark Martins would take over as Chief Prosecutor of the Office of Military Commissions in October 2011. Martins is one of the Army's most well-respected lawyers, and his transfer to GTMO signals the premium the Obama Administration has placed on ensuring the commissions are viewed as legitimate going forward. ${ }^{76}$ In the UCMJ and military commissions, the Office of the Chief Prosecutor typically is led by a JAG lawyer, who operates in close collaboration with the convening authority. Under the MCA, prosecuting attorneys (or "trial counsel," as the MCA calls them) need not be members of the military. Although each commission case has at least one JAG officer assigned, the institutional composition of the prosecutorial team has varied. ${ }^{77}$ Martins has made transparency an office priority, updating the military commission public website, setting up a remote viewing site in the Washington, D.C. area for those interested in observing commission proceedings, and speaking openly about the process to the press and national security community. He also has initiated a new wave of prosecutorial hires. But while those who know Martins best are sanguine about his ability to improve the appearance of fairness and transparency

("Military commissions, even under the more stringent MCA regime, and unlike the time-honored institution of the courts-martial, are still subject to political involvement at several important junctions-most notably, prosecutorial discretion and rule-making procedures."). While the courts-martial system has been criticized over time as being subject to political and command pressures, it is generally viewed as a fair criminal justice system. See Benson \& Lewis, supra note 6. But see Luther C. West, A History of Command Influence on the Military Justice System, 18 UCLA L. REV. 1 (1970).

76. See Peter Finn, Pentagon Names New Guantanamo Prosecutor, WASH. Post, June 23, 2011, available at http://wapo.st/j1CtZZ; Jack Goldsmith, Mark Martins to Be Chief Prosecutor, Military Commissions, LAWfare Blog (June 23, 2011, 5:38 PM), http://bit.ly/VXaOyg; Benjamin Wittes, The Next Step in Establishing the Legitimacy of Military Commissions, LAWFARE BLoG (July 1, 2011, 3:32 PM), http://bit.ly/mSWYZ1.

77. For instance, while the Jawad and al Bahlul cases were prosecuted by JAG lawyers, the Hamdan prosecution team was comprised largely of Department of Justice lawyers, led by lawyers from OLC, and including an Assistant U.S. Attorney and Department of Justice National Security Division lawyers. See Mil. Comm'n Interview 9/7, supra note 48; Mil. Comm'n Interview 9/2, supra note 44. JAG prosecutors learned early on that the Secretary of Defense intended to shift prosecutorial responsibility to attorneys from the Department of Justice's National Security Division out of concern that JAG lawyers lacked sufficient experience to try terrorist cases. See Ruling on Mot. to Dismiss, United States v. Hamdan, CMCR No. 09-002 (Ct. Mil. Comm'n Rev. 2007), available at $\mathrm{http} / / / \mathrm{bit} . \mathrm{ly} / \mathrm{Os} 9$ osB. 
of the commissions, ${ }^{78}$ questions remain about whether the commission's problems are capable of repair.

\section{Office of the Chief Defense Counsel}

As in the UCMJ system, the Office of Chief Defense Counsel in the commission system is subject to a military chain of command, but the commissions' unique institutional dynamic ensures that the office operates in a much different climate than does its courts-martial counterpart. The convening authority in courts-martial is the commander of a group of service members, including the service member on trial. As such, he or she has some interest in the well-being of the defendant and, more importantly, a strong interest in the appearance of a just result, as the purpose of a court-martial is to maintain good order and discipline among the ranks. In contrast, the convening authority in the commission system is a political appointee who has little shared identity or interest in the well-being of a charged terrorist. He or she may have an interest in ensuring a fair proceeding to ensure ongoing public support for the commissions and international support for counterterror efforts, and generally out of respect for rule-of-law principles. As a political appointee charged with the task of convicting suspected terrorists, however, the military commission convening authority does not have the same incentive as a courts-martial convening authority to ensure the fullest, most rigorous adversarial process. For instance, in both courtsmartial and the commission system, defense counsel relies on the convening authority for staffing and for funding its investigators, experts, and (in capital cases) civilian counsel. The political nature of the military commission convening authority, however, results in distinct differences in the freedom with which defense counsel operates in the commission system and in defense counsel's perception of whether they are being dealt an even hand.

The political nature of the convening authority is not the only significant distinction between the two systems for JAG defense counsel. In the UCMJ system, JAG defense lawyers act in a chain of military command that often includes the convening authority, but these lawyers also have a chain of command outside and apart from the leadership and authority of a convening authority in the form of each military's legal services division. For instance, a JAG lawyer stationed at an Air Force base in the U.S. Western Region may seek funding from the convening authority or commanding officer of the Air Force base where the court martial is located; however, he or she may also have recourse to the

78. See sources cited supra note 76 . 
senior defense counsel for the Western Region, who is a member of the Air Force Legal Services Agency and is thus outside the convening authority's control or influence. ${ }^{79}$ JAG lawyers in the Office of Chief Defense Counsel do not have similar recourse.

Although funding for the Office of Chief Defense Counsel has improved under the current convening authority, Bruce MacDonald, historically it has been inadequate. ${ }^{80}$ In its infancy, the convening authority for the military commissions developed a reputation among commission defense counsel for heavily favoring the prosecution: the common view among defense lawyers was that Susan Crawford, who served as convening authority from 2007 to 2010 , had only one stamp on her desk, and it said "denied." She routinely would reject funding, travel, investigative, and expert requests, even when those requests were plainly necessary or supported by the prosecution. ${ }^{82}$ In response, defense counsel have been creative to make up the difference, doing their best to employ cost-free litigation tools. Specifically, defense counsel makes full use of their ability to speak publicly about their cases and to lobby foreign governments to seek and accept transfer of the detainees they represent, tactics that have occasionally engendered the irritation of the prosecution and convening authority. ${ }^{83}$

79. Mil. Comm'n Interview 9/7, supra note 48 .

80. Telephone interview with Military Commission Defense Counsel (Aug. 5, 2011) [hereinafter Mil. Comm'n Interview 8/5]; see also David S. Kris, Law Enforcement as a Counterterrorism Tool, 5 J. NAT'L SEC. LAW \& POL'Y 1, 65-66 (2011) (noting outstanding questions regarding adequacy of resources available to defense counsel; Prosecuting Terrorists: Civilian and Military Trials for GTMO and Beyond: Hearing Before the Subcomm. on Terrorism \& Homeland Sec. of the S. Comm. on the Judiciary, 111 th Cong. 7 (2009) (statement of Jeh Johnson, Gen. Counsel, DOD) (expressing concern that defense counsel receive adequate training and resources to handle capital cases)).

81. Mil. Comm'n Interview 8/5, supra note 80. Susan Crawford was appointed to Convening Authority from her position as chief of staff to David Addington, then-Vice President Cheney's outspoken and hawkish legal counsel. Scott Horton, The Great Guantanamo Puppet Theatre, HARPER's MAG (Feb. 21, 2008, 8:24 AM), http://bit.ly/RU13Oi.

82. Decl. of Lt. Col. Darrel J. Vandeveld I 5, United States v. Jawad, CMCR No. 08-004 (Mil. Comm'n Guantánamo Bay, Cuba Sept. 22, 2008) [hereinafter Vandeveld Decl. 1], available at http://bit.ly/Qrpro3 (noting Convening Authority's refusal to authorize the defense to have an independent physician review Jawad's health records, notwithstanding his support for the motion).

83. Defense counsel has also relied upon pro bono assistance from nonprofit organizations like the ACLU, individual pro bono attorneys, and various law schools, including Duke and Yale, whose students have provided invaluable research and, occasionally, brief-writing assistance. See News Brief, The Guantanamo Defense Clinic: Three Years of Groundbreaking Litigation, 27 DuKE L. MAG. 1, 10 (Winter 2009), available at http://bit.ly/SXIRXY; Susan Gonzalez, Yale Law School Students Fighting for Justice for Guantanamo, YALE NEWS, Apr. 3, 2009, available at http://bit.ly/UVYAkR; Mil. Comm'n Interview 8/5, supra note 80. 
In recent years, the financial and staffing independence ${ }^{84}$ of the Office of Chief Defense Counsel has improved, largely due to the appointment of less openly political leadership in the convening authority and Office of Chief Prosecutor's office. Nevertheless, the reality of the commission system is that defense counsel's ability to advocate effectively for their clients is dependent in large part upon the benevolence of the convening authority: a political entity. For instance, current convening authority Bruce MacDonald has granted the Chief Defense Counsel authority to veto the proposed transfer of defense counsel if he or she so chooses and to approve any military lawyers appointed as defense counsel, which provides the Office of Chief Defense Counsel some personnel control. ${ }^{85}$ None of these institutional protections, however, are mandated by the MCA or any of the regulations or rules created for the commissions; rather, they are essentially a gift of the current convening authority, a military officer interested in improving the commission's fairness. Accordingly, there are no structural or institutional guarantees that this convening authority's generosity will carry forward. Indeed, defense counsel's ability to access funds, to adequately staff its cases, and to ensure the independence of its personnel is subject to the whims of the convening authority, just as it was in 2001. This presents a problem not only in terms of the system's basic fairness, but also in terms of the ethical challenges such uncertainty and politicization place on defense counsel.

\section{OBSTACLES TO ETHICAL COMMISSION LAWYERING}

The commission history and structure detailed above explains the unique legal and political dynamics at work within the commission system-dynamics in part responsible for the ethical obstacles JAG lawyers face in the commissions. Yet, to understand the ways in which this system amplifies similar, but distinct, ethical challenges seen in Article III and UCMJ courts, one must understand how the JAG institutional identity shapes lawyers' responses to the commissions' unique structure. This Part will engage in that analysis. A close inspection of the commissions' structure, as seen through the lens of JAG

84. In the early days of the commissions, all military defense counsel were individually selected by the Convening Authority for their posts. While many lawyers volunteered for a defense post at GTMO, others were simply assigned. See, e.g., Frakt, supra note 11, at 1371 (noting that he volunteered and was selected to serve as military commission defense counsel). Defense counsel Charles Swift, who represented Salim Hamdan, actually requested to be detailed to the prosecution, but was detailed to the defense instead. Luban, supra note 11, at 2007. Interestingly, Morris Davis volunteered for assignment to defense counsel but was assigned to the Office of Chief Prosecutor instead. See Morris Davis Interview, supra note 32.

85. Frakt, supra note 11, at 1371. 
lawyers, reveals that the professional disincentives for conscientious ethical conduct, the ever-present specter of political manipulation, and the lack of clarity in commission law that hangs over each ruling amplify the typical ethical pressures inherent in terrorist prosecution in any forum. These obstacles to ethical decision-making favor conviction in a way not seen in Article III courts or courts-martial, thus raising doubts about the viability of the commissions as a forum for terrorist prosecution.

Although a line of scholarship exists dedicated to the perspectives of the lawyers on the front lines in Guantanamo Bay, ${ }^{86}$ this scholarship has been overlooked in the larger debate over the constitutionality and general appropriateness of the military commissions as a forum for trying suspected terrorists. Likewise, the larger debate has done little to incorporate the important work of legal ethicists like David Luban and Norman Spaulding, whose scholarship focuses on lawyers, their ethical challenges, and the ways in which lawyers shape the production of law. ${ }^{87}$ Focusing on the ethical challenges faced by different groups of lawyers on the ground at Guantanamo Bay unites these disparate strains of scholarship to provide new insight into whether the commission system functions as it should. This on-the-ground ethical analysis reveals that the commission system is in need of reform.

Lawyers operating in various capacities in the military commission system are subject to institutional, bureaucratic, and political pressures that are in tension with the rules of professional responsibility. Although the public resignations and dramatic lawyering of JAG commission lawyers to date suggest that many of these lawyers have refused to allow disincentives to ethical lawyering to cloud their professional judgment, it is impossible to know if, where, and how other lawyers have failed to act with the same moral valor. The fact that JAG lawyers have been called upon to act in such dramatic fashion to call attention to the failings in the commission system-many of which remain unchanged despite recent

86. See Frakt, supra note 11; Lahav, supra note 11; Ivey, supra note 11; Margulies, supra note 11.

87. See David Luban, Legal Ethics and Human Dignity 131-32 (2007); see also Anthony V. Alfieri, Prosecuting the Jena Six, 93 CORNELl L. REV. 1285, 1309 (2008) (noting how Professor Luban's ideal of moral activism "locates moral responsibility for injustice in the daily practice of law," such as the judgment of local prosecutors that can be made based on "insider's and outsider's perspectives of moral obligation"); Susan Carle, Structure and Integrity, 93 CORNELL L. REV. 1311 , 1313 (2008) (citing with favor Luban's inquiry into the integrity of individual lawyers and how integrity operates within an institutional role); of. Norman Spaulding, The Rule-of-law in Action: A Defense of Adversary System Values, 93 CORNELL L. REV. 1377, 1408-11 (2008) (analyzing the role of individual lawyers with regard to the torture memoranda but advocating for a greater focus on the adversarial process to more fully understand these issues). 
reforms-raises serious questions about the capacity of the commission system to dispense justice.

Although JAG lawyers' dual role as officer and lawyer may make them more likely than civilian lawyers to face professional disincentives to principled lawyering when operating in a military justice system, their unique rule-of-law-based institutional identity in some respects makes them better-suited to participate in this hotly adversarial and highly political criminal justice system. Indeed, the early days of the commission system may have played out differently, perhaps with fewer resignations, had the Office of Chief Prosecutor been staffed with volunteer DOJ prosecutors rather than JAG officers. To some extent, JAG lawyers' personal and institutional commitment to the rule of law makes them the perfect subjects to test this newly minted criminal justice system.

This Part will assess the institutional identities and ethical obligations of the lawyers on the front lines of the Guantanamo military commissions-a necessary predicate for understanding whether the current military commission system is conducive to ethical conduct and the principles of justice and fairness. This analysis reveals that multiple factors, including the lack of clarity in commission law, the specter (or reality) of political manipulation, and the professional disincentives facing a military lawyer who fully embraces either a minister of justice or advocate role, impact the choices made by JAG counsel. These factors cumulatively make conviction more likely than it would be in other court systems, thus calling into question the legitimacy of the commission system.

\section{A. Professional Independence and JAG Institutional Identity}

JAG lawyers are widely recognized as a rare breed of lawyer, and their unique institutional identity makes them well suited for work in the military commissions. As David Luban observed:

In obvious ways, JAGs' identity as lawyers sets them apart from other military officers. Some, to be sure, began their career as warriors [but] . . [ [w] hile many JAGs regard themselves proudly as warriors and lawyers, common-sense psychology suggests that their dual identity may make them more, rather than less, zealous than civilian lawyers in their defense of rule-of-law values. ${ }^{88}$

JAG lawyers' stubborn adherence to the rule of law is well known. Their institutional intransigence has caused professors Glenn Sulmasy and John Yoo to question whether the JAG Corps' observance of the rule

88. Luban, supra note 11, at 2000. 
of law, even when in tension with command authority, represents a challenge to civilian control of the military. ${ }^{89}$ As Lieutenant Colonel Colby Vokey, former counsel to Omar Khadr, explained: "[T]he oath [military officers take] is to support and defend the constitution of the United States. ... [Y]ou're not swearing to the president or to a general; that's what your oath is, to support and defend the constitution." effect, the rule of law is the JAG lawyer's commander-in-chief. ${ }^{91}$

The multiple roles JAG lawyers play as part of their jobprosecutor, military advisor, or defense counsel, depending on the daystrengthen this institutional identity. Although many of the JAG lawyers on either the defense or prosecution side of the commissions were chosen for their respective positions at personal request, thus manifesting identification with one side or the other, ${ }^{92}$ a large number of the JAG lawyers serving on the front lines of the military commissions are there simply because they are following orders. Because JAG lawyers frequently switch back and forth between prosecutor and defense counsel, their institutional and ethical identities are more closely tied to the JAG Corps and its ideals than to specific adversarial roles. ${ }^{93}$ In contrast, advocates in the federal court system frequently have very strong personal associations with their role as prosecutor or defense counsel. ${ }^{94}$ The JAG lawyer's lack of entrenched institutional affiliation with either the prosecution or the defense reduces a lawyer's natural inclination to form a partisan bias that could shade ethical judgment, thereby increasing the likelihood that a JAG will operate from an independent perspective. ${ }^{95}$

89. See Glenn Sulmasy \& John Yoo, Challenges to Civilian Control of the Military: A Rational Choice Approach to the War on Terror, 54 UCLA L. Rev. 1815 (2007).

90. David J.R. Frakt, The Myth of Divided Loyalties: Defending Detainees and the Constitution in the Guantanamo Military Commissions, 43 CASE W. RES. J. INT'L L. 545 , 559-60 (2011) (citing Michelle Shepard, Khadr Goes On Trial, TORONTo STAR, Apr. 29,

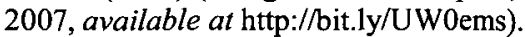

91. See Laura A. Dickinson, Military Lawyers on the Battlefield: An Empirical Account of International Law Compliance, 104 AM. J. INT'L L. 1, 9 (2010). JAG lawyers receive significant rule-of-law training beyond the law degree they must acquire from an accredited law school; they also participate in regular training from seasoned JAG officers over the course of their career. Id. at 112-13.

92. Mil. Comm'n Interview 8/5, supra note 80 .

93. See Cassandra Burke Robertson, Judgment, Identity, and Independence, 42 CONN. L. REv. 1, 4-5 (2009).

94. See generally Anthony V. Alfieri, Lynching Ethics: Toward a Theory of Racialized Defenses, 95 MICH. L. REv. 163, 1086-87 (1997) (describing "roledifferentiated morality" phenomenon among prosecution and defense counsel).

95. Dickinson, supra note 91, at 6; see also Robertson, supra note 93, at 6 ("[T] stronger [the lawyers'] partisan affiliation with their clients or with a related social cause, the greater the risk that they will lack an independent perspective."). 
The usefulness of lawyering from a perspective unattached to a specific adversarial role has been widely discussed in legal scholarship. Cassandra Burke Roberston of Case Western Reserve Law School relies on social science literature to argue that, when lawyers adopt wholeheartedly an adversarial role or scientific cause, this partisan affiliation frequently and unconsciously dictates the way in which they perceive evidence and evaluate the merits of their case. ${ }^{96}$ Accordingly, a lawyer with a strong partisan identity may lose the ability to operate with competent and independent judgment, ${ }^{97}$ a serious problem when, as in the commission system, he or she is called upon to make challenging ethical judgments with significant professional and national security consequences. While JAG lawyers are as subject to partisan biases as any other lawyer, their devotion to the rule-of-law, rather than a partisan identity, may insulate them somewhat from unconscious biases that otherwise might cloud legal judgment. ${ }^{98}$

Norman Spaulding's "thin professional identity" model appears to corroborate that conclusion. Spaulding advocates grounding a lawyer's role in what he calls a "logic of service," rather than in close identification with a specific client's cause. ${ }^{99}$ In other words, ethical lawyering occurs most reliably when lawyers focus their efforts on serving their client without closely identifying themselves with their client's interests. Spaulding describes lawyers operating under a service norm as possessing "thin professional identity," which he explains is a "commitment to the principle that effective service and open access to law demand uninhibited orientation of their faculties towards the realization of their clients' lawful objectives."100 He contrasts this "thin identity," which he views as the ideal, with "thick professional identity," in which a lawyer comes to so closely identify with her client that representing that individual becomes a self-interested pursuit, a "perversion of the service norm." 101 Spaulding asserts such perversion is more likely to result in professional misconduct and broader ethical problems like role confusion, lawlessness, and misdistribution of legal

96. See generally Robertson, supra note 93 (discussing various unconscious cognitive biases that impact legal judgment, such as selective attention, selective recall, selective interpretation, and bias blind spot).

97. Id. at 9.

98. See generally Robertson, supra note 93.

99. See Norman W. Spaulding, Reinterpreting Professional Identity, 74 U. CoLO. L. REV. 1, 3-8 (2002) (discussing the legal ethics concept of "identification," in which lawyers are to assume their clients' interests as a "second self"); see also Norman W. Spaulding, Professional Independence in the Office of the Attorney General, 60 STAN. L. REV. 1031 (2008); Norman W. Spaulding, Independence, Experimentalism, and Resistance to Law in the Department of Justice, 63 STAN. L. REV. 409 (2011).

100. Spaulding, supra note 99, at 7-8.

101. Id. 
services. Legendary defense attorney Robert Bennett articulated the same concern with regard to the dangers of acquiring this type of "thick identity" with a client's cause: "[Y]ou must never become so close to your clients that you lose your independence, objectivity, or ability to do what is right," warning that it can result in "slanted" advice. ${ }^{102}$

Applying Spaulding's legal ethics framework, JAG lawyers' experience as prosecutor, defense counsel, and legal advisor provides them a distance from a specific adversarial role, a distance that improves their ability to subscribe to a "thin professional identity" model. Their focus on the rule of law is strikingly similar to the focus on "the principle of effective service and open access to law" that Spaulding advocates. This focus stands in contrast to the dangerous "thick professional identity" frequently battled by lawyers linked exclusively to either the prosecution or the defense, lawyers who so intensely identify with their own role in the adversarial system or with their client that professional misconduct or role confusion is more likely. ${ }^{103}$ In other words, JAG lawyers' institutional commitment to the JAG Corps, rather than an adversarial role, may make them better suited to balance difficult ethical obligations when those are in conflict with their own personal interests. ${ }^{104}$

Indeed, the military commission system has been a case study in brave and assertive lawyering in the face of ethical challenges. While opponents of the commission system might attribute these aggressive moral actions to a reaction to the deep unconstitutional unfairness of the system, ${ }^{105}$ the JAG's ingrained institutional commitment to ethical duty and the principles of fairness that undergird the courts-martial system (e.g., no unlawful command influence), are widely acknowledged as equally powerful factors. Major General Charles J. Dunlap, Jr. and Major Linell A. Letendre, career JAG lawyers themselves, explained the institutional culture this way:

102. Robert S. Bennett, Ethics, Zealous Advocacy, and the Criminal Defense Attorney, CARDOZO LIFE (Winter 2001), at 27, available at http://bit.ly/Ro3MQA.

103. Spaulding, supra note 99 , at $7-8$.

104. Others have surmised that JAG "mission creep," or the expanding functions JAG lawyers have provided the military in recent years (from running elections and approving bomb targets to writing contracts for construction projects and compensating injured civilians) actually signals a "thickening" identity on the part of the JAG Corps, in which their identity is becoming more closely tied to the military. Elizabeth L. Hilleman, Mission Creep in Military Lawyering, 43 CASE W. RES. J. INT'L L. 565, 568 (2011). This trend may pose a concern for JAG professional independence, as JAG lawyers may become more closely tied to a military identity and more distanced from a rule-of-law or legal identity. On the other hand, JAG lawyers who play an expanded role and are forced to defend the rule of law against military commanders in a multiplicity of circumstances may become more devoted to their institutional identity as rule-of-law defenders.

105. See Luban, supra note 11, at 2000, 2005. 
For JAGs, candid counsel goes beyond our ethical obligation of communicating candid advice to our clients; it is, quite simply, part of our mission. Valor requires JAGs to act affirmatively on issues, report and handle misconduct, deliver bad news, and, where appropriate, disagree with one's superior. Quite notably, the ability of JAGs to deliver candid and independent counsel is preserved by statute. $^{106}$

It is this institutional commitment to truth telling and candor that has inspired such a visceral reaction among the JAG lawyers to the significant ethical challenges resultant from the political nature of the military commission system. ${ }^{107}$

Given JAG lawyers' clear position in a military command structure, some scholars have speculated that this ethical high-mindedness would give way when in tension with the wishes of a superior officer. ${ }^{108}$ While others have disputed that a "divided loyalty" problem exists for JAG lawyers, ${ }^{109}$ most argue that a divided loyalty problem exists, but that somehow it has not noticeably altered the lawyering seen in the military commission system. ${ }^{110}$ The fact that this divided loyalty problem has not played a visible role in the commissions may be due to some extent to the opacity of commission proceedings, ${ }^{111}$ but clearly also is due to the strong JAG institutional identity, which inculcates in its lawyers strong, even dogged, adherence to the rule of law and ethical lawyering. Although a JAG lawyer may differ in the degree to which he or she selfidentifies as an officer versus a lawyer, and this variance may impact the degree to which JAG lawyers prioritize the rule of law over the chain of

106. Charles J. Dunlap, Jr. \& Linell A. Letendre, Military Lawyering and Professional Independence in the War on Terror: A Response to David Luban, 61 STAN. L. REV. 417 (2008) (citing 10 U.S.C. $\$ 8037$ (F) (2000)).

107. $C f$. Dickinson, supra note 91 , at 14 (recounting the results of her 2010 empirical study of the JAG corps as demonstrating that the JAG culture is one of "a military committed to the law of war and the fair treatment of detainees"); see also David Luban, The Conscience of a Prosecutor, 45 VAL. U. L.R. 1, 15 (2010).

108. Frakt, supra note 90, as 559-60 (2011) (citing commentary from Matthew Ivey, David Luban, and Erwin Chemerinsky).

109. Frakt, supra note 90, at 563 ("Military defense counsel assigned to defend detainees before the military commissions felt no divided loyalties.").

110. See, e.g., Ivey, supra note 11, at 238-39; Luban, supra note 11, at 2004; Erwin Chemerinsky, Navy Is Wrong to Force out Guantanamo Lawyer, L.A. DAILY J., Oct. 23, 2006.

111. Even with the Office of Chief Prosecutor's new policy of broadcasting GTMO hearings, because so much commission lawyering occurs behind closed doors and involves classified information, the fact that a phenomenon has not been "noticed" is not evidence that it does not exist. 
military command, ${ }^{112}$ the most-told stories of the military commissions have been of brave JAG assertions of professional independence.

Virtually every seasoned JAG lawyer has a story about the time he or she was called upon to "buck the system," to risk professional promotion for the sake of defending an undesirable defendant or giving unwanted rule-of-law advice on the battlefield. Interestingly, some proudly acknowledge that they did face negative career consequences as a result of their ethically-correct choice. ${ }^{113}$ For a distressingly high number of JAG participants in the commission system, their work on the military commissions is that story. That the commissions require lawyers to risk negative career consequences is problematic and troubling, as it speaks to the politicization of the system and the subtle command influence that may be present. More troubling, however, is the fact that even the JAG Corps' powerful institutional identity cannot guarantee that every lawyer faced with this challenge will respond by choosing the moral high ground, regardless of the professional consequences. The prevalence of these significant ethical challenges in the commission system makes conviction more likely in the military commissions than in other forums for reasons that have nothing to do with the guilt or innocence of the accused.

112. In a survey of several hundred in-house corporate counsel, researchers determined that these lawyers' legal and ethical decision-making was often a function of which identity, either as an employee of the corporation ("organizational" identity) or as a lawyer ("professional" identity), they viewed as more salient. Robertson, supra note 93, at 13-14 (citing Hugh Gunz \& Sally Gunz, Hired Professional to Hired Gun: An Identity Theory Approach to Understanding the Ethical Behaviour of Professionals in NonProfessional Organizations, $60 \mathrm{HUM}$. REL. 851, 859 (2007)). Like in-house corporate counsel, JAG lawyers' decision-making may vary based on which of their dual identities-as a military officer or as a lawyer-predominates. Accordingly, one might expect JAG counsel whose "professional" identity as a lawyer is most salient to engage in the type of come-what-may aggressive advocacy demonstrated by many commission defense lawyers. One has to wonder, however, how those lawyers whose "organizational" identity is most salient-whose strongest identity is as an officer rather than as a lawyer-may respond to the unique pressures of operating within a politicized military hierarchy. For instance, would a prosecutor whose salient identity is an organizational one respond with indignation, as Morris Davis did, to the close supervision of the Convening Authority's Legal Advisor, or would he or she prioritize the judgment of superior officers, despite the prosecutorial independence suggested by the MCA? Given the inappropriateness of political forces dictating criminal justice outcomes, or of the criminal justice system's use for political purposes, a salient "professional" identity would seem to be most desirable for counterbalancing the opacity and potential manipulation of the commission system.

113. See generally Frakt, supra note 90. 


\section{B. Ethical Challenges of the Office of the Chief Prosecutor}

Prosecutors in every system operate under regular ethical pressure, but the commission system amplifies these pressures to a degree beyond that seen in other criminal justice systems. Extensive scholarship exists regarding the prosecutor's role in the criminal justice system, most frequently centering on the obligation to serve as a "minister of justice." 114 The American Bar Association's Criminal Justice Section, Standard 3-1.2 (c) explains: "The duty of a prosecutor is to seek justice, not merely to convict." 115 U.S. Supreme Court Justice George Sutherland highlighted this dual prosecutorial role in 1935:

[The prosecutor] is in a peculiar and very definite sense the servant of the law, the two-fold aim of which is that guilt shall not escape or innocent suffer. He may prosecute with earnestness and vigorindeed, he should do so. But, while he may strike hard blows, he is not at liberty to strike foul ones. It is as much his duty to refrain from improper methods calculated to produce a wrongful conviction as it is to use every legitimate means to bring about a just one. ${ }^{116}$

Balancing prosecutorial zeal with a commitment to justice is a constant challenge for prosecutors in any system. In the commission system, the challenges of this balancing act are significantly amplified by the nature of the crimes committed, the institutional framework of the individuals prosecuting the cases, the asymmetry of informationgathering, the heavy historic politicization of the system, and the high profile of the cases. Unlike the usual criminal case, where the victim or victims are individuals unknown to the prosecutor, terrorist crimes are directed against the United States, which the prosecutor has sworn to protect and defend, and against its citizens, a group to which the prosecutor belongs. Military prosecutors, who have taken an oath to defend their country against such violence, and many of whom have witnessed terrorist attacks firsthand on the battlefields of Afghanistan or Iraq, might feel the personal nature of terrorist crimes even more keenly.

Balanced against this personal stake in terrorism prosecution, of course, is the JAG lawyers' ethically centered institutional identity. JAG

114. See Daniel S. Medwed, The Zeal Deal: Prosecutorial Resistance to PostConviction Claims of Innocence, 84 B.U. L. REv. 125, 132 (2004) ("The primary responsibility of prosecution is to see that justice is accomplished."); Judith A. Goldberg \& David M. Siegel, The Ethical Obligations of Prosecutors in Cases Involving Postconviction Claims of Innocence, 38 CAL. W. L. REv. 389, 393 (2002) ("No ethical prosecutor should ever oppose the pursuit of justice. ...").

115. ABA Standards for CRIMINAL Justice: ProseCution and DefENSE FunCtion 3-1.2 (c) (3d ed. 1993).

116. Berger v. United States, 295 U.S. 78, 88 (1935). 
prosecutors have been vigorous defenders of rule-of-law protections for terrorist suspects, as evidenced by the public resignations and statements of commission prosecutors like Morris Davis, Darrel Vandeveld, and Stuart Couch. ${ }^{17}$ Some of the heightened ethical pressures JAG lawyers experience in the commissions are a function of their military membership, but other challenges are felt equally strongly by their civilian colleagues in the Office of the Chief Prosecutor. For this latter category of challenge, the JAG Corps serves, to some extent, as the canary in the mine - a warning of a toxic ethical environment apparent only because of the JAGs' heightened sensitivity to rule-of-law deviations.

\section{The Problem of Prosecutorial Volunteerism}

The ethical challenges inherent in terrorist prosecution have been compounded in the commission context by reliance on volunteers to fill the pool of prosecutors. ${ }^{118}$ Some JAG prosecutors have volunteered for this duty because of close personal connections to victims of terrorism and, therefore, a personal connection to prosecution efforts. For instance, former JAG prosecutor Stuart Couch lost a close friend in the September 11th attacks-a Marine buddy who had co-piloted one of the flights that hit the World Trade Center. ${ }^{119}$ Couch volunteered to serve on the prosecution because he wanted to "get a crack at the guys who attacked the United States" 120 - a sentiment which does not exactly evoke a "minister of justice" mindset. Likewise, for JAG lawyers who spent time in combat in Afghanistan or Iraq, who may have fought against insurgents or lost colleagues to insurgent or terrorist attacks, the goal of terrorist conviction may seem synonymous with the goal of pursuing justice. ${ }^{121}$ Self-selection within the prosecution team and its

117. See Josh Meyer, For Lawyer, Trial Was Tribulation, L.A. TIMES, Oct. 12, 2008, available at http:/lat.ms/ij6Xj9 (referencing Darrel Vandeveld's resignation as, at minimum, the fourth resignation of a prosecutor in protest of the military commission system).

118. See David J.R. Frakt, Closing Argument at Guantanamo: The Torture of Mohammed Jawad, 22 HARV. HuM. RTs. J. 401, 404 (2009) (referencing the Armed Services' request for each branch to solicit JAG officers to serve on the commissions and the Air Force's resultant request for volunteers).

119. See Jess Bravin, The Conscience of the Colonel, WaLL St. J., Mar. 31, 2007, available at http://bit.ly/QsNao3.

120. Id.

121. As former commission prosecutor Darrel Vandeveld explained, when he joined the commission, it was "to further [his] desire for revenge for the September 2001 attacks, and to avenge those Americans who had not survived their tours of duty," a goal which he saw as "protecting and defending the Constitution and our Nation, as well as contributing in some small measure to ensure that the fallen had not done so in vain." 
attendant personal commitment to punishing terrorists has a tendency to bring with it a bias, a "thick identity," 122 which makes maintaining the evenhanded, open-minded "minister of justice" role more challenging. Where, as in the commissions, the prosecutorial team is comprised of volunteers from across the government (e.g., the Justice Department's National Security Division (NSD), Office of Legal Counsel, U.S. Attorneys' offices, and the DOD), all of whom share similar incentives and predispositions in favor of conviction, these personally-invested prosecutors may operate under the perception that the team reflects diverse neutral perspectives when, in fact, all share the same bias in favor of conviction. ${ }^{123}$

JAG lawyers' institutional commitments to the rule of law may make them better suited for such ethical predicaments. Commission prosecutor Stuart Couch, as discussed infra, made a brave ethical choice to resign from a case notwithstanding his professed interest in terrorist conviction. Couch's description of the soul-wrenching decision-making process he went through-weeks of sleeplessness, depression, anxiety, and consultation with a religious authority-leaves no doubt that there are significant ethical challenges for commission prosecutors in fulfilling their "minister of justice" role and potentially increased challenges when a personal interest is at stake. ${ }^{124}$ Fortunately, JAG prosecutors often naturally gravitate toward the "minister of justice" ideal due to previous

Interview with Darrel Vandeveld, THE MODERATE VOICE, Feb. 21, 2009, http://bit.ly/Rj563H.

122. Spaulding, supra note 99 , at 23-27.

123. See Medwed, supra note 114 , at 132 ; see also Frakt, supra note 11 , at 87 ("[B]ecause the Office of Military Commissions relied in large part on volunteers to fill the ranks of the prosecution and defense, quite a few of the defense counsel and prosecutors were not only personally committed to their cases or clients, but also they were often philosophically and ideologically committed to the positions they were advocating"). See generally Robertson, supra note 93, at 7-9 (discussing the impact of "partisanship"-being assigned to advocate for a particular side-on an individual's perception of reality and observing that often it results in selective attention to facts advantageous to the designated side). While it is not unusual for Article III prosecutions to be performed by a collaborative group of Justice Department lawyers (often joining NSD lawyers with Assistant U.S. Attorneys (AUSAs) from the district where the charges have been brought), these lawyers largely are not "volunteers" in the same sense that they are in the commission system: they may have chosen a career with Justice, but they generally have not volunteered for a specific type of prosecution. Obviously, NSD lawyers have chosen a career in counter-terrorism work, but they typically are assigned to specific assignments not by their own choice but by the decision of their superiors based on their skill set, workload, and experience. The AUSAs are assigned using those same considerations and by virtue of their employment in the particular district in which the case was filed. While some small degree of self-selection may be involved in terms of who is assigned to which case, by-and-large assignment to a specific type of case is not self-initiated, thereby mitigating the risk of the conviction-focused tunnel vision that might otherwise accompany a largely volunteer prosecutorial team.

124. See Bravin, supra note 119. 
experience as defense counsel, experience that allows them to review evidence and enforce the law in a way less likely to be tied to a strong prosecutorial identity and more likely to be objective. Similarly, JAG prosecutors share natural bonds with opposing JAG counsel through their common institutional identity and JAG experience and, occasionally, shared military service. ${ }^{125}$

In addition, while JAG lawyers certainly stand to gain professionally by obtaining a conviction, the professional benefits of a military commission win are far less significant for a JAG attorney than for a DOJ lawyer, for whom it may provide a platform for professional advancement or political appointment. As veteran JAG lawyer David Frakt described the military promotion system: "Promotions . . . are largely based on leadership ability, as reflected in officer performance reports, rather than on performance or skill as an attorney." ${ }^{26}$ An important prosecutorial victory will receive a mention in a JAG lawyer's promotion report, but it is a far less significant consideration in determining promotion or future assignment than the type of leadership experience one would receive in a lower-profile alternative post. ${ }^{127}$ In other words, a stunningly successful prosecution in the military commission system is not likely to be a career maker in the way that it could be for an Assistant U.S. Attorney. ${ }^{128}$

\section{Ethical Challenges in Applying the Brady Framework in the Commission System}

Prosecutors in all criminal justice systems face ethical challenges in determining how best to comply with the constitutional disclosure requirements imposed by the Supreme Court's Brady ${ }^{129}$ line of cases, but even more so in the military commissions. ${ }^{130}$ Determining what

125. In Hamdan, prosecution and defense counsel had served together as JAGs in the field and maintained their close friendship and cooperation throughout the Hamdan trial. Mil. Comm'n Interview 9/2, supra note 44.

126. See David Frakt, Winning Detainee Hamdan's Case Didn't Prevent Navy Lawyer's Promotion, L.A. DAILY J., Nov. 7, 2006.

127. Id.

128. Indeed, because the military prizes leadership experience over litigation experience, a victory in the commission system, where proceedings often extend over years, would require multiple consecutive litigation tours and, therefore, would be more likely to damage, rather than enhance, promotion prospects.

129. Brady v. Maryland, 373 U.S. 83, 87 (1963).

130. See id. ("We now hold that the suppression by the prosecution of evidence favorable to an accused upon request violates due process where the evidence is material either to guilt or to punishment, irrespective of the good faith or bad faith of the prosecution."). Although, in the early days of the military commissions, it was not clear whether the Brady disclosure rule applied in the military commissions, the Military Commissions Act of 2006 erased that confusion. See Vandeveld Decl. 1, supra note 82, 
evidence qualifies as "exculpatory" and warrants disclosure on that basis comes with a host of practical challenges. Because only "material," exculpatory information need be disclosed by the prosecution, prosecutors are required to make an independent determination regarding the materiality of the evidence in their possession. ${ }^{131}$ This determination is far from intuitive and requires prosecutors to stand in the shoes of an appellate court-often well before trial strategy is set-and weigh the importance of the evidence, the strength of the rest of their case, and other sources of evidence available to and used by the defense. ${ }^{132}$ Indeed, prosecutors are required to apply the Brady standard prospectively. Under the law, prosecutors must disclose exculpatory evidence in a "timely manner," which requires them to assess the strength of their case and the importance of the particular piece of evidence before their investigation is complete, before all evidence is in hand, before receiving evidentiary rulings that will determine the scope of the evidence they may use, and before trial reveals the defense strategy to which they may need to tailor their case. ${ }^{133}$

In the commission system, standing in the shoes of an appellate body-particularly in the early stages of a commission proceedingpresents an incredible challenge. The commission system requires application of an entirely new set of untried hearsay rules-rules with no precedent to guide prosecutorial decision-making. Moreover, by statute, the commission system has no precedent at all-other than the handful of previous military commission opinions-for prosecutors to use in assessing whether evidence will be admissible. ${ }^{134}$ Where intelligence agencies collect the majority of evidence in a case, this already difficult task is made all the more onerous. Intelligence agencies are notoriously reluctant to supply evidence to prosecutors for use in criminal processes ${ }^{135}$ and have been known to withhold from military commission prosecutors material details regarding, for instance, the interrogation procedures used to elicit evidence that formed the basis of the

If 5 (noting the Convening Authority's refusal to authorize the defense to have an independent physician review Jawad's health records).

131. See Daniel Medwed, Brady's Bunch of Flaws, 67 WASH. \& LeE L. Rev. 1533, 1541 (2010).

132. See id.; see also Daniel S. Medwed, Prosecution Complex: America's Race TO CONVICT AND ITS IMPACT ON THE INNOCENT (2012).

133. Id. at 1542 .

134. See 10 USC $\S 948 b$ (b)-(c) (2006 \& Supp. 2009).

135. See JACK GOLDSMITH, THE TERROR PRESIDENCY: LAW AND JUDGMENT INSIDE THE BUSH ADMINISTRATION 90-91 (2007) (noting intelligence agencies' risk aversion and occasional resistance to White House orders due to their fear of "retroactive discipline," which is after-the-fact punishment for actions they were instructed to take). 
commission charges. ${ }^{136}$ Because the method of obtaining the information may play a major role in determining its admissibility (e.g., what types of interrogation methods elicited the evidence), this withholding of information makes a Brady determination challenging on a few levels: first, this type of information almost certainly would qualify as exculpatory; second, this lack of full information regarding sources and methods (and therefore admissibility) may leave prosecutors without an accurate sense of what their case ultimately will be, and therefore what evidence meets the definition of "exculpatory." As former commission prosecutor Darrel Vandeveld recalled, at the time charges were sworn against commission defendant Mohammed Jawad, the prosecution had "absolutely no idea" Jawad had been subjected to abusive treatment of any kind-the records in their custody showed no evidence of injury. ${ }^{137}$ Only later did they discover that Jawad had been subjected to highly abusive treatment while in both Afghan and U.S. custody, including administration of the "frequent flyer" program. ${ }^{138}$ Where information regarding collection processes and interrogation techniques has been withheld from commission prosecutors, the prosecutors must make decisions regarding disclosure with a much-reduced sense of the scope of evidence they may ultimately use in their case or the admissibility of that evidence.

This concern is present in any terrorism/national security case but becomes amplified in the military commission setting, where judges historically have been reticent to question the government's classification determinations or to force it to share evidence with the defense. ${ }^{139}$ The

136. See Marie Brenner, Taking on Guantanamo, VANITY FAIR (Mar. 2007), available at http://vnty.fr/OZjVwZ (discussing former defense counsel Swift's recollection that, in the early days of the commissions, several of the prosecutors who were frustrated at having been denied evidence by the CIA during discovery had confided to him that "the C.I.A. has taken this over," and that despite their best efforts, it was difficult to get evidence out of the intelligence agencies). See generally Decl. of Lt. Col. Darrel J. Vandeveld, United States v. Jawad, CMCR No. 08-004 (Mil. Comm'n Guantanamo Bay, Cuba Jan. 12, 2009) [hereinafter Vandeveld Decl. 2], (describing prosecutor's "[H]erculean" effort to secure all relevant evidence in Mohammed Jawad case), available at $\mathrm{http}: / / \mathrm{bit} . l \mathrm{ly} / \mathrm{QsU} 3 \mathrm{pd}$.

137. See Vandeveld Decl. 2, supra note 136, \11.

138. See id. The "frequent flyer" program refers to the subjection of detainees in U.S. military custody to extreme sleep deprivation, typically in conjunction with interrogation. See Jamil Dakwar, Guantanamo's Frequent Flyer Program, ACLU BLOG OF RIGHTS (June 20, 2008, 4:45 PM), http://bit.ly/TIJiUE.

139. See NAT'L InST. Mil. JUST., RePORTS FROM GUANTANAMO VOlume I, at 5 (report of Jonathan Tracey), available at http://bit.ly/TIJXoZ [hereinafter GUANTANAMO REPORTS III] (noting that "the defense had to fight for every piece of evidence and rarely won all the evidence it was entitled to receive"). Broad judicial deference to government decisions regarding classification can be crippling to the defense because such determinations often limit the defense's ability to discuss evidence and strategy with their clients, deprive them of direct access to documents and witnesses, and require them to 
concern is also amplified where new, relatively untried military commission rules of evidence leave looming questions over what evidence ultimately will be admissible. ${ }^{140}$ These factors combine both to allow prosecutors broad discretion with regard to evidentiary disclosure and to severely limit the information they have available when making that determination. The objectivity of commission judges has been widely criticized by defense counsel and others, who allege that the commission judiciary too often defers to the prosecution. ${ }^{141}$ Indeed, under the MCA, commission judges essentially are commanded to be highly deferential to the government regarding what evidence may be shared with defense counsel and under what circumstances. ${ }^{142}$ These decisions are potentially game changing, such as whether evidentiary summaries produced by the government to replace classified exculpatory evidence or witness testimony are sufficient, or whether defense counsel can question specific witnesses or view specific documents. ${ }^{143}$

This pressure to side with the government is magnified by the fact that military judges typically have little experience with the type of highvolume classified information management required in a commission

apprise the prosecution in advance any time they seek to use classified information in court, which often forces advance disclosure of trial strategy and legal arguments. See Mil. Comm'n Interview 9/13, supra note 57. According to Judge Leonie Brinkema, who tried the Zacarias Moussaoui case, judicial oversight is particularly important given the government's penchant for keeping evidence classified to avoid embarrassment rather than for national security purposes. See Doug Kramer, Federal Judge Says Courts Can Handle Gitmo Cases, Cleveland NEws (Apr. 2, 2009, 11:06 PM), http://bit.ly/UYlbe0.

140. See Vladeck, supra note 6.

141. Complaints by the Chief Defense Counsel's Office of lack of impartiality among judges include complaints that military judges (1) allow prosecutors to set the agenda for the hearings, often letting the prosecution to argue motions that the court has expressly told defense counsel would not be discussed in the proceeding and (2) give the government the benefit of every possible evidentiary ruling, particularly when classification is even tangentially involved. See Pet. for Writ of Mandamus and Writ of Prohibition at 19-20, In re Al Shibh, No. 09-1238 (D.C. Cir. Sept. 9, 2009). Other groups have also observed a pro-prosecution bias. A former JAG observer from the National Institute of Military Justice noted that "the defense had to fight for every piece of evidence and rarely won all the evidence it was entitled to receive." GuANTANAMO REPORTS III, supra note 139 , at 5.

142. See supra Part I.C.1 (discussing differences in judicial role under CIPA versus MCA).

143. See supra Part I.C.1 (discussing differences in judicial role under CIPA versus MCA); see also Jennifer Elsea, Cong. Research Serv., RL 31600, The Department of Defense Rules for Military Commissions: ANalysis of Procedural Rules and Comparison With Proposed Legislation and the Uniform Code of MILITARY JUSTICE 15-16 (2006) (citing 10 U.S.C. $§ 950 w$ ); United States v. Moussaoui, No. 01-455, 2003 WL 2123699 (E.D. Va. Mar. 10, 2003) (requiring the prosecution to allow standby defense counsel access to GTMO detainee witnesses or risk exclusion of that testimony); Amos N. Guiora, Creating a Domestic Terror Court, 48 WASHBURN L.J. 617, 621 (2009) (describing classification decisions made by Eastern District of Virginia Judge Leonie Brinkema in the Zacarias Moussaoui case as "highly problematic"). 
proceeding, as these types of cases are rare in courts-martial. Likewise, because military commission judges are tasked with ruling on international and constitutional law issues of first impression (issues to which courts-martial judging provides little exposure), reviewing hundreds of pages of briefing, and performing these tasks under the watchful eye of the media, it is not surprising that these judges would err on the side of the government. This government-leaning tendency is particularly likely where these rule-of-law-minded JAG officers are forced to wade through uncharted legal territory, unmoored from the guidance of rules and precedent to which they are accustomed and in a system where there effectively is no precedent. ${ }^{144}$ As with judges in the courts-martial system, judges in the commission system serve without set terms and with few institutional protections. ${ }^{145}$ This lack of institutional protection is problematic in the military commission system, however, where political forces are prevalent and where judges may consider themselves closely watched. ${ }^{146}$ Given these pressures, it would not be surprising if military judges (consciously or not) tended to err on the side of jurisprudential caution by ruling in ways that advance conviction over acquittal. $^{147}$ Regardless of whether commission judges in fact defer to

144. See 10 U.S.C. $\$ 948$ b(c) (2006 \& Supp. 2009).

145. See Major Fansu Ku, From Law Member to Military Judge: The Continuing Evolution of an Independent Trial Judiciary in the Twenty-First Century, 199 MiL. L. REV. 49, 57 (2009). The Military Commissions Act prohibits, as does the Uniform Code of Military Justice, the review of any judge by the Convening Authority or his staff with regard to that judge's performance of duty as a military judge. See 10 U.S.C. $\S 948 j(h)$ (2006 \& Supp. 2009); see also UCMJ art. 26(a) (2012). Without life tenure or a fixed term, however, while the review prohibition prevents a military judge from being removed from his post expressly because of a ruling, in practice, a military judge lacks real substantive insulation from removal so long as that removal can be justified on other grounds. See DOD, MANUAl For Military COMmissions, at II-12 (2010) (stating that the Convening Authority may, under Military Commission Rule 109, refer a military judge for professional discipline). Perhaps tellingly, unlike the UCMJ, the MCA does not require the President to prescribe procedures governing the investigation and disposition of matters concerning the fitness of military judges. See UCMJ art. 6(a) (2012).

146. When Commission Judge Army Colonel Peter Brownback retired suddenly, some speculated that he was forcibly retired because of a controversial ruling in the al Bahlul case (granting al Bahlul's pro se request) or because he threatened prosecutors with suspending proceedings against Omar Khadr unless they produced records related to the conditions of his confinement. Mil. Comm'n Interview 9/7, supra note 48; see also Khadr Judge Fired, Says His Military Lawyer, CBC NEws (May 29, 2008, 10:05 PM), http://bit.ly/UY50Qm. While the reason for Brownback's forcible retirement was never made public, the timing of the decision was sufficiently coincidental, immediate, and unexplained that it engendered widespread speculation. Certainly, at the least, the nature of his removal is enough to cause other military judges to consider carefully rulings that are potentially controversial.

147. Harvard Law Professor Bill Stuntz observed federal judges' aversion to risktaking with regard to reversal and the resultant conservative management of discovery and trial. See William Stuntz, The Uneasy Relationship between Criminal Procedure and 
the government more often than do federal judges, commission lawyers' perception that commission judges favor the prosecution may affect prosecutorial decision-making in any event, as the risk of facing serious consequences for failing to make Brady disclosures or engaging in gratuitous classification may be perceived as low.

These complicating factors, along with intelligence agencies that are empowered by court deference and unclear admissibility rules, make the military commission prosecutor's task of ensuring Brady compliance even more challenging than it is in civilian criminal courts. ${ }^{148}$ The task is sufficiently daunting that commission prosecutors effectively are discouraged from engaging in the type of Brady review conducted in civilian or courts-martial proceedings, since repeated requests for evidence are likely to bear little fruit. ${ }^{149}$

The incentive to under-disclose in the military commission context is bolstered by the low likelihood of independent discovery of Brady materials by the defense. Prosecutors, as a general matter, engage in Brady deliberations without supervision or review, performing these important and often consequential constitutional analyses without public disclosure. $^{150}$ In military commission cases, prosecutors have little reason to worry that defense counsel might independently stumble across

Criminal Justice, 107 YALE L.J. 1, 13-16 (1997). Of course, while the safe course for federal judges with regard to reversal and public opinion is to allow the utmost in criminal procedure protection, see id., for military judges, the safe course with regard to reversal and public opinion generally is to rule in favor of the government.

148. The challenges faced by military commission lawyers in the Brady context are further complicated by the overlay of state ethical responsibilities with which they must comply to maintain good standing with their state bar associations. Many states have added additional layers of protection to the obligations identified in Brady and its progeny, embedding more stringent disclosure requirements in their ethical rules, which are binding on JAG lawyers in those state jurisdictions while in practice before the military commissions. See Bruce A. Green, Beyond Training Prosecutors About Their Disclosure Obligations: Can Prosecutors' Offices Learn from Their Lawyers ' Mistakes?, 31 Cardozo L. Rev. 2161, 2165 (2010); R. Michael Cassidy, Prosecutorial Ethics $70-71$ (2005) (" $[\mathrm{T}]$ he use of the term 'tends' in Rule 3.8(d) and its predecessor, ABA Model Code provision DR 7-103(b), was likely intended to suggest a broader disclosure obligation than the 'materially exculpatory evidence' standard of Brady and its progeny.").

149. See Vandeveld Decl. 2, supra note 136, If 8 (noting complete lack of organization of commission investigation files).

150. As Professor Daniel Medwed observed, "When a prosecutor chooses not to disclose evidence, that decision is seldom revealed to outsiders unless he later has a change of heart or it somehow finds its way into defense hands." Medwed, supra note 114, at 1542 (citing Bennett L. Gershman, Litigating Brady v. Maryland: Games Prosecutors Play, 57 CASE W. REs. L. REV. 531, 537 (2007) (listing various ways undisclosed evidence may be discovered, including Freedom of Information Act requests, independent investigation by defendants or their relatives, discovery during post-trial motion hearings, and by chance). 
withheld evidence ${ }^{151}$ or that a military judge may order production of exculpatory evidence improperly identified as classified and produced in summary form. The crimes alleged largely took place on faraway battlefields located in remote, dangerous regions - crime scenes which may be inaccessible to the defense because of national security concerns or resource limitations and, even if accessible, have been compromised by the passage of time and wartime damage. Intelligence agencies have gathered virtually all of the evidence against the defendants through interrogations of the defendants, other detainees, and intelligence assets, and this evidence is classified; therefore, it is beyond the reach of defense investigators. ${ }^{152}$ The independent discovery problem is also seen in federal courts (e.g., in United States v. Ghailani ${ }^{153}$ ), but is exacerbated in the commission system by judicial deference and severely limited defense funding. ${ }^{154}$ Each of these hurdles for defense counsel make independent discovery of Brady materials highly unlikely, thus providing no counterweight to the natural incentives of a prosecutor to withhold Brady evidence. ${ }^{155}$ Accordingly, commission prosecutors may be more likely to err on the side of caution in withholding potentially exculpatory evidence.

151. Prosecutors have had such a difficult time gathering evidence from intelligence agencies and, with the disorganization of the files they do receive, even the most dedicated of prosecutors cannot guarantee that all exculpatory evidence has been disclosed. Commission prosecutor Darrell Vandeveld infamously stumbled across a key piece of exculpatory evidence against commission defendant Mohammed Jawad in a random locker at GTMO. See Vandeveld Decl. 2, supra note 136, IT 8, 25. Vandeveld's lack of confidence in his ability to guarantee compliance with Brady obligations, among other concerns about the fairness of the military commission system, ultimately led him to resign from his commission post. See id. $\mathbb{T} 29$.

152. In the pending cases against the alleged $9 / 11$ co-conspirators, the government has classified statements that the defendants made to government interrogators prior to being represented by counsel. See Mil. Comm'n Interview 9/13, supra note 57 . However, military commission defense counsel are prohibited from communicating with their clients regarding statements those clients have made to interrogators, further limiting defense counsel's ability to investigate that evidence. See id.

153. United States v. Ghailani, 761 F. Supp. 2d 167 (S.D.N.Y. 2011).

154. Even assuming the defense independently located undisclosed Brady evidence, the odds of success in bringing a Brady claim in federal court historically have been remarkably low. Defendants likely would face similarly long odds in the commission system. See Medwed, supra note 114, at 1543 ("When Brady issues do come to light, the materiality test is a heavy burden for a defendant to overcome on appeal. Appellate courts are frugal in doling out Brady reversals.").

155. See Rachel E. Barkow, Organizational Guidelines for the Prosecutor's Office, 31 CARDOZo L. REv. 2090, $2091-92$ (2010) (discussing incentives for prosecutorial Brady violations). 


\section{Professional Disincentives for Raising Ethical Challenges}

While many deride the ideal of the upright, impartial prosecutor as a fanciful notion ${ }^{156}$-particularly given the challenges inherent in a terrorist trial-it is just this type of commitment to the rule of law that has played out in the Office of the Chief Prosecutor over the past ten years. Although one could argue that the brave actions of these principled prosecutors should serve to reinforce public confidence in the military commission system, the reality is that the remarkably high number of these resignations in such a short time period is compelling evidence of a troubled system. There have been no institutional reforms that would remedy these types of ethical challenges. The fact that this type of ethical bravery was required of so many - and the fact that, for every courageous prosecutor whose actions are lauded in the press, there may well be others making less courageous choices that are far less publicized or perhaps undiscoverable ${ }^{157}$-raises real concerns about the legitimacy of the commission system going forward.

In its relatively short history, the commission system has seen seven prosecutors-including two Chief Prosecutors-resign from specific cases, the commission system, or the service entirely because of perceived ethical improprieties tied to the commissions. ${ }^{158}$ It is no surprise that the vast majority of these lawyers have been JAG officers with long histories in the courts-martial system, a criminal justice system which has come to be generally viewed as insulated from political pressure. ${ }^{159}$ When confronted by political pressure to obtain convictions at any cost, to use evidence obtained through torture, to bring cases without merit or prematurely, or upon discovering that relevant exculpatory information would never be produced, these prosecutors

156. See Steven K. Berenson, Public Lawyers, Private Values: Can, Should, and Will Government Lawyers Serve the Public Interest?, 41 B.C. L. REv. 789, $792-94$ (2000) (discussing the public interest serving mission of prosecutors); Kenneth Bresler, Pretty Phrases: The Prosecutor as Minister of Justice and Administrator of Justice, 9 GEO. J. LEGAL ETHICS 1301, 1301-02 (1996) (observing that the phrase "minister of justice" is largely a platitude without genuine implications for prosecutorial conduct).

157. See, e.g., Vandeveld Decl. 2, supra note 136, ๆ 22 (recounting astonishment at witnessing his putative superior, Chief Prosecutor Colonel Lawrence Morris, allow Brigadier General Hartmann to give technically correct, but not fully candid, answers to questions in a hearing regarding Hartmann's alleged unlawful influence in the Jawad case).

158. Daniel Schulman, Is the Army Forcing Out a Gitmo Whistleblower?, MOTHER JONES (May 31, 2010, 3:00 AM), http://bit.ly/aNTZLI (referencing Morris Davis and Fred Borch).

159. David J.R. Frakt, Indelicate Imbalance: A Critical Comparison of the Rules and Procedures for Military Commissions and Courts-Martial, 34 AM. J. CRIM. L. 315 (2007). 
made the difficult decision to take an ethical stand. ${ }^{160}$ The decisions made by these individuals to resign from the commission system were fraught with self-doubt and emotional hardship and, for several, lasting professional consequences. As Darrell Vandeveld recalled of former Chief Prosecutor Morris Davis, "There is no doubt on the part of those who know him, that Col. Davis would have been elevated to the rank of general officer had he not refused to be bullied by members of the [Bush] Administration...."161 Rather than receiving a promotion, Davis was notified that he had "not serve[d] honorably" in the commissions because of his resignation, and he was denied a medal for his service as prosecutor. $^{162}$

Moreover, JAG prosecutors who choose to defend their "minister of justice" role may risk the social stigma of refusing to prosecute cases their colleagues - and in some cases senior officers - view as completely valid. Stuart Couch recounted his experience of telling then-Chief Prosecutor and senior officer Army Colonel Bob Swann that he would not prosecute an assigned case for moral and legal reasons (all useable evidence was a product of torture). Swann's response was swift, personal, and indignant: "What makes you think you're so much better than the rest of us around here?"163 Couch is quick to point out that he suffered no career setback as a result of his decision. Indeed, he continued as a commission prosecutor on his other assigned cases. ${ }^{164}$ While Couch may have paid only a collegial price, others, like Morris Davis, were not so lucky. ${ }^{165}$ All of these individuals, however, were forced to make potentially career-ending decisions in choosing whether to follow the course they viewed as the ethical one.

160. This is true even of individuals who had full conviction in the guilt of at least some of the potential defendants. Colonel Morris Davis, former Chief Prosecutor and current harsh Guantanamo critic who resigned his post due in part to the efforts of the DOD to dictate what cases he proceeded on first, has stated that with respect to "seventyfive or eighty [detainees,]" he believed there was "reliable evidence to prove they had violated the law of war in the past." Fmr. Chief Guantanamo Prosecutor Says Military Commissions "Not Justice," DEMOCRACY NOw! (July 16, 2008), http://bit.ly/dvJusJ (interviewing Colonel Morris Davis, former Chief Prosecutor, Office of Military Commissions).

161. The Talking Dog, TD Blog Interview with Darrel Vandeveld, THE TALKING Dog (Feb. 20, 2009), http://bit.ly/TgMGAX.

162. See McNeal, supra note 68, at 133 (citing Josh White, Colonel Says Speaking Out Cost a Medal, WASH. POST, May 29, 2008, at A09).

163. See Bravin, supra note 119.

164. See id.

165. See, e.g., McNeal, supra note 68, at 133 (recounting Former Chief Prosecutor Morris Davis's allegations of retaliation); Vandeveld Decl. 1, supra note 82, I 12 (observing official retaliation against former prosecutors Morris Davis and William Britt). 
Regardless of whether official retaliation occurred against those prosecutors who spoke out or was merely perceived by some, the existence of these allegations of retaliation and the known possibility of it ensures that professional risk will be a consideration for JAG prosecutors going forward. The perceived risk will impact commission lawyering, increasing the likelihood of less ethical conduct. Given the difficulty of the ethical decisions faced by commission lawyers, their frequency, and the incredible courage required in following the most principled course, it is likely that for every prosecutor who refused to proceed with a prosecution, others did so despite misgivings. ${ }^{166}$ For instance, former prosecutor Darrel Vandeveld described the professional dangers associated with trying to perform his prosecutorial ethical obligation to pursue justice, ${ }^{167}$ admitting that he had previously declined to share certain exculpatory evidence with commission defense counsel out of concern for retaliation if seen to be too cooperative with the defense, a choice justified in his mind by the hope that he might improve the system from within by continuing to participate. ${ }^{168}$ Despite the courageous lawyering exhibited to date by the JAG Corps, it would be naïve to believe that every JAG lawyer would, under the circumstances present in the commissions, place a client's interest before his own; the fact that the commissions requires as much raises questions about the system's legitimacy.

Prosecutors in every criminal justice system struggle to balance complying with the rules of professional responsibility, their individual sense of justice and propriety, and the aggressive pursuit of conviction. Prosecutors in every criminal justice system also struggle with the professional consequences of such decision-making. ${ }^{169}$ Nevertheless, the Office of Chief Prosecutor faces conflicting ethical pressures greater than the pressure faced by prosecutors in a standard court-martial or Article III court. Reasons for such heightened pressure include: (1) the national security interests at stake in trying terrorist suspects, (2) the close public

166. While the decision to risk professional reputation by resigning from the commission or a particular case would be difficult regardless of one's formal military status, Couch's and Vandeveld's resolve may have been strengthened by their status as military reservists, which are lawyers who have legal careers independent from the military. Indeed, at the time Vandeveld served as prosecutor in the commission system, it was not clear that Brady disclosure obligations applied to a commission prosecution. Nevertheless, as a state prosecutor in his non-military career, Vandeveld felt duty bound to comply with Brady requirements.

167. Vandeveld Decl. 1, supra note 82, ๆ 12.

168. Id.

169. See, e.g., Luban, supra note 107 (referencing the story of veteran New York prosecutor Daniel Bibb who was assigned to reexamine two murder convictions that he came to believe were wrongful, but that his supervisors would not dismiss, ultimately causing him to " $\mathrm{d}[\mathrm{o}]$ the best I could ... [ $\mathrm{t}] \mathrm{o}$ lose" the cases in court). 
scrutiny felt by senior officials and the President regarding detainee policy (and therefore by the lawyers executing it), and (3) the additional pressure of being part of a command structure. Individuals like Vandeveld and Couch risked their professional reputations and careers, as well as (in the case of Couch) the conviction of individuals they believed to be terrorists because, in their view, their ethical obligations required it. As former Chief Prosecutor Morris Davis described his commitment to the military commission process:

I was the chief prosecutor for the military commissions at Guantanamo Bay, Cuba, until Oct. 4, the day I concluded that full, fair and open trials were not possible under the current system. I resigned on that day because I felt that the system had become deeply politicized and that I could no longer do my job effectively or responsibly. ${ }^{170}$

Darrel Vandeveld explained his decision to resign in similar terms: "I became the seventh military prosecutor at Guantanamo to resign because I could not ethically or legally prosecute the defendant within the military commission system at Guantanamo." ${ }^{\prime 17}$ The JAG lawyers made courageous ethical choices in service to their deep, institutional, rule-oflaw commitments, and the fact that they were forced to make such choices attests to a challenging ethical environment. Despite the many examples of moral courage and professional independence exhibited by the JAG prosecutors at Guantanamo Bay, the regular and significant ethical pressures they face call into question the functionality and legitimacy of the commission system.

\section{Ethical Challenges of the Office of the Chief Defense Counsel}

JAG defense counsel have an impressive history of ethical lawyering in the military commissions, regularly providing a fullthroated defense of the rule of law and their clients despite significant ethical pressures. In the time-honored tradition of defense counsel, JAG lawyers from the Office of the Chief Defense Counsel have been required to adopt the role of zealous advocate notwithstanding potential professional consequences for themselves. It is a role for which, as discussed supra, JAG lawyers are institutionally well suited. ${ }^{172}$ While defense counsel in any criminal justice system grapple with difficult

170. Morris Davis, AWOL Military Justice, L.A. TIMEs, Dec. 10, 2007, at 15.

171. Testimony of Lt. Col. Darrel Vandeveld (USA Reserves): Hearing on Legal Issues Surrounding the Military Commissions System Before the Subcomm. on Constitution, Civil Rights, \& Civil Liberties of the H. Comm. on the Judiciary, 111 th Cong. 19 (2009).

172. See supra Part II.A. 
ethical questions regarding zeal, confidentiality, trust, and primacy of the client's interest, particularly in high profile cases, ${ }^{173}$ the ethical demands placed on JAG defense counsel by the commission system have been extraordinary. As one JAG defense recalled of his military commission experience, "I practiced military law for fourteen years without ever needing an ethics opinion. Here, I needed several of them before I ever got a client." 174

The National Association of Criminal Defense Lawyers has openly discouraged its members from acting as civilian counsel at Guantanamo Bay, noting that " $[t]$ he rules regulating counsel's behavior are just too restrictive to give us any confidence that counsel will be able to act zealously and professionally." $" 175$ The Office of Chief Defense counsel lawyers themselves have been deeply divided over the propriety of working within the commission system, despite what they view as embedded unfairness for their clients. By engaging in reform efforts, they may improve the rights available to their clients, but in doing so they also decrease the likelihood of reversal of their clients' convictions on constitutional grounds. ${ }^{176}$ The ethical challenges embedded in the commission system repeatedly have required defense counsel to choose between professional reputation and advancement on one hand and their duty to their client on the other. JAG defense counsel have, to date, engaged in remarkably zealous high-stakes advocacy on behalf of their clients, despite serious obstacles, but their zealousness, commitment, and success should not be grounds on which to ignore the very real ethical challenges they have had to overcome. The fact that these principled lawyers have been called upon to make such sacrifices for their clients indicates an urgent need for reform. This reform is perhaps even more urgent now, as capital punishment is being considered for the $9 / 11$

173. See, e.g., Judith L. Maute, Colloquium: What Does It Mean to Practice Law "In the Interests of Justice" in the Twenty-First Century?: "In Pursuit of Justice" in High Profile Criminal Matters, 70 FORDHAM L. REV. 1745, 1748 (2002).

174. Luban, supra note 11 , at 2007 (citing a telephone interview with a JAG defense counsel on December 3, 2007).

175. Lawrence S. Goldman, Guantanamo: Little Hope for Zealous Advocacy, CHAMPION MAG., at 4 (July 2003), available at $\mathrm{http}: / /$ bit.ly/TMdOgj.

176. The Office of Chief Defense Counsel has been internally divided over whether its clients are best served by efforts to improve the commission process, or whether participation in reforms adds legitimacy to a system that is fundamentally broken. The Office ultimately decided to let defense counsel reach their own decisions on the issue. See Mil. Comm'n Interview 9/7, supra note 48; Associated Press, Navy Lawyer Who Faulted Guantanamo Is Reassigned, N.Y. TIMES, Apr. 4, 2009, available at http://nyti.ms/12XY9N (reporting Khadr defense counsel's statement faulting the Chief Defense Counsel for cooperating with the Obama Administration in determining the forum for trying detainee cases: "I don't want to make it easier for the government to prosecute my client. ... I want my client to be released."). 
conspirators and as an increasing number of civilian defense counsel enter the commission system-lawyers who may so closely identify with their adversarial role and the detainees' cause that the serious ethical challenges inherent in commission lawyering become less perceptible. ${ }^{177}$

\section{Ethical Challenges in Operating Within a Chain of Command}

Some of the most significant obstacles to ethical lawyering arise from the unique structure of the commission system. The Convening Authority's control over defense funding and defense counsel's own interest in future advancement within the military creates strong disincentives for zealous advocacy. Operating within a chain of command is nothing new for JAG defense counsel, but operating within a political chain of command is. Not only is seeking funding from a political entity a challenge, but defense counsel also have wrestled in the early days of the commissions with open attempts by DOD political appointees to direct their lawyering. As Charles Swift, one of the first defense counsel detailed to the commissions recalled, during the period before defense counsel were assigned clients, DOD General Counsel William J. Haynes treated them as his staff attorneys, asking them to perform tasks for the Convening Authority aimed at strengthening the commission process. ${ }^{178}$ When defense counsel protested on grounds that such assistance would facilitate the ultimate conviction of their clients and was not ethically appropriate, their protests were brushed aside. ${ }^{179}$ Haynes's orders placed the newly detailed counsel in the challenging position of estranging the DOD General Counsel (a move not likely to be advantageous to career advancement) and potentially the Convening Authority (upon whom they relied for funding) in favor of clients whose identity they had not yet learned and whose needs they did not yet know.

177. One might argue that, given the inherent professional disincentives faced by military defense counsel in the commission system, relying on civilian defense counsel may ameliorate the system's ethical problems. Such an argument underappreciates the importance of JAG lawyers to the commission system. First, because the military commission system is fundamentally a courts-martial-based system, JAG experience and familiarity with the rules are essential. Second, many of the ethical challenges faced by defense counsel in the commission system are not unique to JAG lawyers-civilian lawyers and military lawyers alike feel the threat of investigation and challenges associated with negotiating a guilty plea. Third, because of their unique rule-of-lawbased institutional identity, JAG lawyers' special sensitivity to ethical conflicts has been highly important in recognizing and highlighting needed improvements in the commission system, some of which are the focus of this article, which civilian lawyers less familiar with the military system may not have detected.

178. See Luban, supra note 11, at 2006-07 (citing a telephone interview with Charles Swift on December 10, 2007).

179. See id. 
This tension between zealous un-conflicted advocacy and professional advancement has been a recurrent theme for commission defense counsel. Although some have asserted that this tension is not a significant factor for JAG lawyers, ${ }^{180}$ there can be no dispute that professional advancement and reputation influence decision-making to some degree, even for JAG lawyers. As is true for lawyers in other fields who operate with dual identities, some JAG officers may more closely associate with one aspect of their professional identity over the other: professional advancement may be a less salient concern for those JAG lawyers who view themselves primarily as lawyers rather than officers, and may be a more salient consideration for those JAG lawyers who view themselves more as officers than lawyers. ${ }^{181}$ Further, even those JAG lawyers who care little about promotion may care a great deal about professional punishment or damage to their professional reputations, a risk also extant in the commission system.

Nor is there any doubt that many JAG lawyers who have vocally opposed the commission system have faced negative professional consequences following their commission service. Major Mori, defense counsel to Australian David Hicks, used vociferous public advocacy, lambasting the commission system, to win public support for his client in Australia and, ultimately, leveraged this political capital to obtain a highly favorable plea deal for his client. Mori was reassigned immediately after his representation of Hicks concluded and later complained that he was passed over twice for promotion. ${ }^{182}$ William Kuebler, defense counsel to Canadian Omar Khadr, likewise waged an aggressive publicity campaign in hopes of securing his client's release. ${ }^{183}$ Chief Prosecutor Lawrence Morris's response was a personal attack on Kuebler's professional reputation: he stated that Kuebler ("[o]ne defense counsel in particular") had "habitually flouted the rules" and was "grossly distorting" and "fabricating information."184 Commission prosecutors likewise reported retaliation after speaking out against ethical improprieties in the commission system. ${ }^{185}$ This perceived

180. Frakt, supra note 90 , at 556 ("JAGs are not motivated solely, or even primarily, by a desire to be promoted and the attendant increase in financial remuneration.").

181. See Robertson, supra note 93; see also supra note 112 (discussing dual identity).

182. Michael J. Lebowitz, Anti-War \& Anti-Gitmo: Military Expression and the Dilemma of Licensed Professionals in Uniform, 43 CASE W. RES. J. INT'L L. 579, 595 (2011) (citing Dunlap \& Letendre, supra note 106, at 436-37).

183. See William Glaberson, An Unlikely Antagonist in the Detainees' Corner, N.Y. TIMES, June 19, 2008, available at http://nyti.ms/RmmAwf.

184. Id.

185. Former Chief Prosecutor Morris Davis reported retaliation following his resignation. McNeal, supra note 68, at 133. Darrel Vandeveld reported witnessing official retaliation against Morris Davis and former prosecutor Army Lieutenant Colonel 
retaliation, whether intended by the DOD as such, has sent a clear message to JAG defense counsel about the types of conduct the commission system values in its lawyers, the consequences of overly aggressive advocacy. Taken together with other similar behavior, these messages have contributed to a negative perception of the commissions' organizational culture, a perception not easily changed. ${ }^{186}$ Regardless of whether this type of retaliation has or would take place in today's military commission system under its new leadership, past retaliation and the lack of protection against its recurrence guarantees its continued role in defense lawyers' ethical decision-making.

\section{Ethical Challenges in Military Lawyering}

As veterans of the courts-martial system, JAG lawyers are well acquainted with the unique challenges inherent in standing opposite their DOD employer when representing defendants, and they are known for doing so zealously. Many seasoned JAG lawyers have tales of rejecting command pressure to throw a case, and most of them recall making the decision to do so with ease. Such is the institutional identity of JAG lawyers. But the military commission system has created a unique dynamic. Not only are these lawyers more dependent on the convening authority than they would be in the courts-martial system, but they also are defending enemies of the state, rather than fellow soldiers, in a proceeding not aimed at maintaining order and discipline, but instead aimed at neutralizing a terrorist threat. Further, due to the nature of the commission proceedings and the circumstances of their client's capture, their most effective advocacy almost invariably is to attack their employer, the methods it used to capture and interrogate their clients, and the fundamental integrity of the commission system it has established. All of these unique aspects of the commission system place JAG lawyers in a challenging position.

JAG officers face significant challenges when their job requires an open attack on the policies promoted by the Commander-in-Chief. ${ }^{187}$

William Britt, who had spoken publicly against Convening Authority Legal Advisor Thomas Hartmann. Vandeveld Decl. 1, supra note 82, ๆ 12.

186. See McNeal, supra note 68, at 133.

187. Commission Defense Counsel Charles Swift described the ethical discomfort inherent in arguing, as a member of the military, that President Bush's military order establishing the tribunals was unconstitutional:

The order had been signed by the president. I knew what that meant. If the president is involved, the first, most important rule is: Don't embarrass him. When the president says you are guilty, you better damn well be guilty. I knew that this was going to be awkward. The job of a military officer is not normally to make the commander in chief look bad.

Brenner, supra note 136. 
Because attacks on the commission system are standard advocacy for commission defense counsel, these lawyers must walk a fine line between verbally attacking the system and running afoul of their professional obligation as service members to refrain from speaking ill of commanding officers. When Dan Mori, counsel for David Hicks, openly charged the military commission system with being rigged, then-Chief Prosecutor Morris Davis suggested Mori could be court-martialed for violating the military-law prohibition against speaking disrespectfully of high U.S. government officials. ${ }^{188}$ At least one commentator has observed that Mori's public advocacy, which included assertions that the military commission system was "created and controlled by those with a vested interest only in convictions," "189 was "in direct contradiction to his duties as a military officer" because he had a professional duty to refrain from criticizing public officials. ${ }^{190}$ If true, ${ }^{191}$ this professional duty would appear to be inherently in conflict with defense counsel's obligation to their clients: as William Kuebler, JAG defense counsel for detainee Omar Khadr, explained: "If we're not advocating against the process, we're not competently representing our clients." 192 For past defense counsel like Mori and Kuebler, as well as for counsel today, the best defense possible may require running afoul of military leadership and their own professional interests, an ethical problem that recent reforms to the commission system have not remedied.

The logistics of military lawyering, including the requirement that JAG lawyers transfer posts every two to three years, have also created ethical challenges for JAG commission counsel. Because of the incredibly slow pace of the military commission proceedings and the mandatory regular transfer of military lawyers, the Office of Chief Defense Counsel has struggled to ensure continuity in detainee representation, with JAG lawyers frequently transferred to new assignments before their detainee's case concludes. While JAG

188. See Luban, supra note 11 , at 2015.

189. Id.

190. Lebowitz, supra note 182, at 594 (observing that Mori's "blistering public comments" to an Australian audience "appeared to violate at least two limitations of military expression": using contemptuous language against government officials and participating in a foreign political demonstration while in uniform) (citing Dunlap \& Letendre, supra note 106, at 436-37).

191. Other observers believe Mori's statements were within the bounds of the ethics rule on trial publicity and were aimed at the military commission system, not officials, and therefore were not in violation of the military rules. See Luban, supra note 11, at 2016; see also Ellen Yaroshefsky, Military Lawyering at the Edge of the Rule of Law at Guantanamo: Should Lawyers Be Permitted to Violate the Law?, 36 HofSTRA L. Rev. $563,572-73$ (2007) ("Davis's notion that Mori could have been prosecuted appears farfetched.").

192. Glaberson, supra note 183. 
reservists called up from civilian life to serve in the commissions may extend their tours virtually indefinitely, JAG lawyers coming from active duty are limited to a one- to three-year stint in the commission system before being detailed to a new assignment. ${ }^{193}$ Moreover, because the military promotion system strongly disfavors litigation details, there are significant disincentives against lawyers extending their Guantanamo assignment beyond one tour, even when doing so may be in their client's best interest. ${ }^{194}$

Short-term assignments work perfectly well within the courtsmartial system, where motions practice is less frequent, precedent generally clear, and trials relatively short, but pose real problems in the commission system. Many JAG lawyers detailed to the commissions come with only one prior detail as defense counsel, meaning two or three years of criminal law experience in the courts-martial system, in which they are defending people charged with minor crimes in single-defendant cases that rarely involve high volumes of classified information. ${ }^{195}$ In other words, some of the JAG lawyers called upon to defend terrorist suspects in the commissions-high-profile cases involving serious crimes - are still relative newcomers to the practice of criminal law. ${ }^{196}$ Even seasoned JAG lawyers struggle under the load of representing Guantanamo detainees in the commission system because important rules and precedent are still entirely unclear and often require JAG lawyers to actively lobby Congress at the same time they bear the load of representing clients in high-profile, sometimes even capital, cases. ${ }^{197}$ Add to these challenges the difficulty of mastering dense constitutional, international, and law of war precedents; complicated classification procedures; and massive, highly disorganized case files, and a two- to three-year assignment is hardly enough time for many JAG lawyers to achieve even the basic level of competency required of a criminal defense lawyer under the rules of professional conduct. ${ }^{198}$

Short-term details present challenges regarding winning and keeping client trust as well. Guantanamo detainees frequently are

193. See Mil. Comm'n Interview 9/13, supra note 57.

194. See supra Part II.B.1 (discussing military promotion system, which favors leadership experience over litigation experience).

195. See Mil. Comm'n Interview 9/13, supra note 57; see also Joshua Dratel, How I Learned to Stop Worrying and Love the Military Commissions, 41 SETON HALL L. REV. 1339, 1351-52 (2011).

196. See sources cited supra note 195.

197. Mil. Comm'n Interview 9/13, supra note 57.

198. MOdel Rules of Prof'L CONDUCT R. 1.1 (2012) ("A lawyer shall provide competent representation to a client. Competent representation requires the legal knowledge, skill, thoroughness and preparation reasonably necessary for the representation."). 
reluctant to meet with appointed counsel, and particularly with a government-appointed military lawyer. These detainees often have been victims of abuse at the hands of U.S. personnel, some of whom shared the uniform of their newly assigned lawyer, and, after a decade of detention, many are understandably suspicious of the quality of justice they are likely to receive at the hands of the U.S. government. One JAG defense lawyer doggedly traveled to GTMO every other week for seven months before the detainee-client would even allow the lawyer an audience. ${ }^{199}$ It took far longer to gain that detainee's trust. ${ }^{200}$ The first lawyer to represent Mohammed Jawad completed his entire one-year tour without being granted Jawad's authorization to actually represent him. ${ }^{201}$ Army Major Amy Fitzgibbons, a reservist, developed a strong working relationship with Sudanese detainee Noor Uthman Muhammed during her one-year detail as his defense counsel, extending her assignment for an additional six months and continuing to serve in a civilian capacity as lead defense counsel after her tour ended. ${ }^{202}$ Nevertheless, despite Fitzgibbons's express wish to continue representing Muhammed, the Army issued orders assigning Fitzgibbons to a new detail in which the representation would not be permitted to continue. ${ }^{203}$ Ultimately, Fitzgibbons obtained the court's assistance in continuing her representation, ${ }^{204}$ but in the process was required to defy the commanding officers for her new assignment, making the difficult choice to risk future promotion prospects and military assignments in the interest of her client. The short-term nature of military assignments is a natural limit on the ability of military counsel to forge and maintain strong client relationships, putting JAG lawyers in the difficult position of either attempting to prolong their assignment-a move inimical to advancement--or taking the new assignment, letting their client relationship lapse, and, in some cases, reaffirming their client's distrust of the commission system.

199. Mil. Comm'n Interview 9/13, supra note 57.

200. Id.

201. Mil. Comm'n Interview 9/7, supra note 48.

202. See Def. Mot. to Retain Military Counsel $\S 4(\mathrm{c})$, (g), United States v. Noor Uthman Muhammed (Mil. Comm'n Guantánamo Bay, Cuba Mar. 17, 2010), available at http://1.usa.gov/Oxo21C.

203. Id.; see also Stacy Sullivan, A Lack of Conviction, ForEIGN POL'Y, Jul. 27, 2010, available at $\mathrm{http}: / / \mathrm{bit} . \mathrm{ly} / \mathrm{TgYeUz}$.

204. See Order D-022: Mot. to Retain Counsel, Dkt. No. AE055A, United States v. Noor Uthman Muhammed (Mil. Comm'n Guantánamo Bay, Cuba Mar. 19, 2010), available at http://bit.ly/uNGVzH. 


\section{Professional Pressures Inherent in Guantanamo Lawyering}

There are a number of ethical challenges specific to Guantanamo lawyering. In the early days of the commission system, the political leadership sought to directly control the scope of defense counsel's representation. When Swift was detailed to represent Salim Hamdan, he was told that his six-week assignment would be to negotiate a guilty plea for his client. ${ }^{205}$ In other words, to gain access to his client at all, Swift was forced to agree to a representation limited to a guilty plea negotiation-an agreement he knew might not be in the best interest of his client. ${ }^{206}$ Although Rule 1.2 of the Model Rules of Professional Conduct states that the client is to determine the objectives of representation, ${ }^{207}$ Swift had to violate this rule in order to access his client. As evidenced by the Supreme Court's Hamdan v. Rumsfeld decision $^{208}$, handed down three years after Swift began his "six-week" representation of Hamdan, Swift ultimately declined to negotiate the 20year prison term deal. ${ }^{209}$ The Convening Authority no longer attempts to set up-front parameters on the length or substance of defense counsel's representation of its client, though there is nothing preventing it from doing so. Nevertheless, commission defense counsel still face the problem of having to agree to government restrictions that they may view as at odds with their ethical duties in order to gain access to their client. $^{210}$

Yet an additional ethical hurdle for commission defense counsel arises in connection with those detainees who have refused counsel or may be mentally incompetent, an ethical challenge which frequently occurs in detainee representation. The 2009 MCA provides detainees the right to qualified self-representation, but earlier versions of the

205. Brenner, supra note 136.

206. Id. Likewise, all lawyers must sign highly restrictive protective orders to gain access to their clients at GTMO.

207. MODEL RULES OF PROF'L CONDUCT R. 1.2(a) (2012).

208. Hamdan v. Rumsfeld, 548 U.S. 557 (2006).

209. Jonathan Mahler, Hamdan: Guantanamo's Mystery Man, TiME, July 21, 2008, available at http://ti.me/5qK6f3. Hamdan was ultimately acquitted of conspiracy but convicted of providing material support to terrorism. He returned home to Yemen within a year of his conviction.

210. These rules, which apply to lawyers with habeas proceedings in Article III courts as well, prevent defense counsel from disclosing to the detainee any classified information-even when that classified information includes statements that the detainee made to interrogators-and restricts defense counsel from discussing anything other than information "directly related to counsel's defense of a detainee in the military commission cases." See Press Release, N.Y. State Bar, New York Bar Association Criticizes Protective Order Affecting Counsel for Guantanamo Detainees (Apr. 21, 2011), available at http://bit.ly/W5Jtdl. 
commissions did not. ${ }^{211}$ Even today, the judge must authorize selfrepresentation. Where such requests have been rejected, defense counsel assigned to represent these detainees find themselves in the unenviable position of either violating the rules of professional ethics or risking contempt of court. $^{212}$ When Major Tom Fleener's client, al Bahlul, requested to represent himself, the judge denied that request. ${ }^{213}$ Fleener refused to return to counsel's table until ordered to do so by the judge. ${ }^{214}$ When al Bahlul was tried before the military commissions in 2008 , he ordered his counsel, David Frakt, not to participate in the commission proceeding. ${ }^{215}$ Faced with a direct, lawful request from his client, Frakt did the only thing he believed he ethically could do: he refused to participate in the commission proceeding, despite a court order to the contrary. Instead, Frakt remained silent while his client was tried and sentenced to life imprisonment. ${ }^{216}$ Although Frakt indicated that al

211. Faretta v. California, 422 U.S. 806,821 (1975) (finding that the Sixth Amendment gives a criminal defendant the right to conduct his or her own defense in a criminal case and, to proceed pro se, the defendant must knowingly and intelligently waive the right to counsel); McKaskle v. Wiggins, 465 U.S. 168, 169 (1984) (holding that the Sixth Amendment is not violated when a trial judge appoints stand-by counsel, even over defendant's objection, in order to ensure that the defendant understands and follows "basic rules of courtroom protocol"); 10 U.S.C. $\$ 949 a(b)(2)(D)$ (2006 \& Supp. 2009) (right to self-representation if "accused knowingly and competently waives assistance of counsel" and "conform[s] the accused's deportment and the conduct of the defense to the rules of evidence, procedure, and decorum applicable to trials by military commission").

212. Model RULES of Prof'L Conduct R. 1.16(a)(3) (2012) ("[A] lawyer shall not represent a client ... if the lawyer is discharged.").

213. See, e.g., Sean Flynn, The Defense Will Not Rest, GQ Mag. (July 2007), available at http://gqm.ag/9t5xJP (recounting the story of William Kuebler and Tom Fleener who were ordered by military commission judge to continue to represent their clients after being fired).

214. Of course, on the other side of the dilemma are the difficult ethical questions associated with the "volunteer" problem: when a client wants to plead guilty out of a desire for execution. Lawyers for the alleged $9 / 11$ co-conspirators have run into this issue head-on, as did counsel for Zacarias Moussaoui who objected repeatedly as his client sought self-representation. See Edward McMahon, Def. Counsel to Zacarias Moussaoui, Defending Terrorists, Remarks at Univ. of Va. Miller Cent. (Jan. 30, 2009), available at http://bit.ly/X6t4n0. Applying David Luban's analysis of the Unabomber representation, in which he condemned Ted Kaczynski's lawyers for portraying him as a lunatic against his will and thereby desecrating his life's work in an effort to save his life, one might ask whether defense counsel acts appropriately when it prevents a detaineeclient set on martyrdom from achieving it. See Luban, supra note 11, at 1983-86.

215. The Guantanamo Docket: Ali Hamza Ahmad Suliman al Bahlul, N.Y TIMES, $\mathrm{http}: / /$ nyti.ms/Tpml36 (last visited Oct. 13, 2012).

216. David Mcfadden, At Gitmo, Life Sentence for Bin Laden Propagandist, USA TODAY (Nov. 4, 2008, 6:14 AM), available at http://usat.ly/RggOQ4. 
Bahlul had several strong defenses, ${ }^{217}$ al Bahlul insisted from the beginning that he would represent himself or not be represented at all.

For those defense counsel representing multiple clients in a system with virtually no precedent, detainees who wish to represent themselves or to boycott the process can present a unique ethical challenge. At the time that Frakt obeyed al Bahlul's request to boycott his trial, Frakt also was zealously defending a client he believed innocent of the charges against him, some of which charges were identical to those al Bahlul was refusing to contest. Frakt was faced with the choice of serving one client's best interest over the best interest of the other: watching the government impose without counter-argument an interpretation of the law in al Bahlul's case that subsequently may be found persuasive by Jawad's judge (a likely outcome given the lack of military commission precedent), or contesting the charges against al Bahlul in direct contravention of al Bahlul's order. ${ }^{218}$ In other words, failure to object to the government's arguments in al Bahlul's case could easily result in those arguments being embraced at the Commission Review level, thereby contributing to binding precedent on future proceedings against Jawad and others. Frakt was forced to perform the legal equivalent of a tightrope walk between the interests of his two clients. Frakt took to communicating with the judge by informal note, in which he would remind the judge that he was precluded from representing al Bahlul, but would speculate regarding what one might argue if one were acting as al Bahlul's attorney. ${ }^{219}$

Defense counsel also have been forced into difficult ethical situations by intrusive government security measures that infringe on attorney-client privilege in the name of national security and which, intentionally or not, chill zealous and effective advocacy. Controversy over whether Guantanamo Bay administrators can review attorney-client mail has been ongoing since the early days of the commission. That controversy heated up in December 2011 when Guantanamo commander Rear Admiral David Woods adopted a rule allowing more expansive review of legal mail. ${ }^{220}$ The Guantanamo military leadership defended

217. Despite al Bahlul's rejection of the commission process, because appeals are automatic in the commission system (and al Bahlul did not order his counsel to file a motion to deviate from this standard practice), his case currently is on appeal to the D.C. Circuit, where some of these questions are likely to be explored. See Brief of Pet'r, al Bahlul v. United States, No. 11-1324 (D.C. Cir. Mar. 9, 2012).

218. Mil. Comm'n Interview 9/7, supra note 48. Judge Gregory already had made clear that withdrawal was not an option. See Andy Worthington, An Empty Trial at Guantanamo, ANDY WORTHINGTON BLOG (Oct. 27, 2008), http://bit.ly/SSPg3E.

219. See supra note 218.

220. Ben Fox, Suit Challenges New Guantanamo Prison Mail Rule, THE GuARdIAN (UK), Feb. 10, 2012, available at http://bit.ly/W5UdZc. Interestingly, in court, a 
the policy as necessary for national and base security, ${ }^{221}$ whereas defense lawyers have decried it as violating attorney-client privilege. ${ }^{222}$ In February 2012, the National Association of Criminal Defense Lawyers' Ethics Advisory Committee instructed commission defense counsel that

[because the Guantanamo review policy] create[s] a conflict between defense counsels' duty to not disclose client confidences without the client's informed consent and counsels' duty to provide competent representation . . . [defense counsel must] cease meaningful communications with their clients to protect confidences. ${ }^{223}$

The opinion was released even as the al-Nashiri judge considered a motion by defense counsel to block review of attorney mail, a request that the military commission court might not have the authority to enforce even if granted. ${ }^{224}$ In the meanwhile, defense counsel was forced to choose between communicating with their clients in preparation for defending the capital charges against them, or avoiding mail communications because of their inability to ensure attorney-client privilege. $^{225}$

The ever-present threat of government investigation also has created ethical challenges for defense counsel. Counsel for alleged 9/11 coconspirator Ramzi bin al Shibh were the subject of an official inquiry initiated by prosecutors under the false assumption that defense counsel

commission defended the new review process as justified due to an al Qaeda-published Inspire magazine "getting in" to detainees. Woods later publicly contradicted that assertion, noting that GTMO censors had intercepted the publication as part of the regular review process. Carol Rosenberg, Admiral: Al Qaida Magazine Didn't Reach Captives, MIAMI HERALD, Mar. 2, 2012, available at http://hrld.us/ySQCVv.

221. See Associated Press, Maryland: Review of Detainees' Mail Is Defended, N.Y. TIMES, Jan. 18, 2012, available at $\mathrm{http}: / /$ nyti.ms/wA6fzP.

222. See Benjamin Wittes \& Ritika Singh, Al-Nashiri \#8: You've Got Mail-And I'm Going to Read It!, LAWFARE BLOG (Jan. 18, 2012, 1:24 PM), http://bit.ly/PuqYO3.

223. NAT'L ASS'N CRIM. DEF. LAWYERS, NACDL ETHICS ADVISORY COMMITTEE OPINION 12-02 (2012), available at http://bit.ly/T117OZ.

224. Questions remain whether commission judges have authority to order the joint task force ("JTF") that runs the Guantanamo Bay Naval Base. When Ibrahim al-Qosi pled guilty, his plea agreement included a provision that he be kept in Camp 4 and not placed in isolation. Ultimately, JTF refused to honor this request, and the judge changed her order from stating that failure to keep al Qosi in Camp 4 would nullify the plea deal to one in which she "'highly recommend[ed]' that al Qosi be placed in Camp 4" but made clear that failure to do so would not violate the plea agreement. Andrea Prasow, $A$ Trial within a Trial: Justice, Guantanamo-Style, JURIST, Aug. 19, 2010, available at http://bit.ly/ST64aI.

225. Chief Defense Counsel for the Military Commissions issued a memorandum to all attorneys analyzing the applicable rules of court and professional conduct and advised defense counsel not to submit attorney-client privileged materials to the Privilege Team for review. See Mem. from U.S. Marine Corps Col. J.P. Colwell, Chief Defense Counsel, to the Office of Chief Defense Counsel (Jan. 13, 2012), available at http://bit.ly/OxRYLc. 
had disclosed classified information to the detainee's habeas counsel. ${ }^{226}$ This investigation forced counsel to respond to these contentions while also pursuing the defense of the detainee and, as part of this investigation, the FBI entered defense counsel's offices and conducted an interrogation regarding purported violations of classified information rules. $^{227}$ Likewise, civilian commission defense lawyer Clive Stafford Smith was called into court in 2009 to respond to charges that he had violated classification rules in a letter written to the President. ${ }^{228}$ None of these charges were ultimately substantiated. ${ }^{229}$

The open threat of investigation of commission defense counsel poses multiple ethical concerns. First, this type of investigation often gives government investigators reason to access sensitive attorney-client privileged information, in violation of the protections guaranteed those communications in federal court. ${ }^{230}$ Second, for military lawyers whose employment depends on their ability to respect classification rules, these types of allegations and the media's coverage of them poses serious risks to professional reputation and advancement. ${ }^{231}$ Third, for those detainees for whom transfer out of Guantanamo Bay is a goal, success often turns on positive media coverage of the case in the press both domestically and abroad, and the tone of that coverage is put at risk by allegations of attorney impropriety and national security violations.

Perhaps most importantly, allegations of security violations are susceptible to opportunistic use because classification determinations are in many cases subjective, entirely within the government's control, and non-appealable. ${ }^{232}$ In an effort to maximize protection of classified

226. Pet. for Writ of Mandamus and Writ of Prohibition at 19-20, In re Al Shibh, No. 09-1238 (D.C. Cir. Sept. 9, 2009).

227. Id. (referencing Peter Finn, Lawyers Showed Photos of Covert CIA Officers to Guantanamo Bay Detainees, WASH. PoST, Aug. 21, 2009, http://wapo.st/28Uelx).

228. Famed Gitmo Lawyer Facing Six Months in Prison for Writing Letter to Obama Detailing Torture of Client, ALTERNET (Apr. 2, 2009), http://bit.ly/QYpKsZ.

229. See id.

230. See, e.g., FED. R. EVID. 502.

231. Allegations of improperly disclosing information to detainee clients is a particularly sensitive charge to defense counsel, perhaps particularly so given the conviction of defense lawyer Lynne F. Stewart for material support of terrorism as a result of improper disclosures she made during her representation of terrorist spiritual leader Omar Abdel Rahman. Gregory P. Noone \& Diana C. Noone, The Military Commissions-A Possible Strength Giving Way to a Probable Weakness-and the Required Fix, 36 CASE W. RES. J. INT'L L. 523, 526 (2004); Lynne Stewart, Defending the Right to Defend, 2 SEATTLE J. SOC. JUST. 85 n.14 (2003).

232. In some commission cases, the intelligence agencies have delegated to the prosecution the ability to deem evidence classified. The incentives of intelligence agencies naturally veer toward over-classification, and the fact that defense counsel must notify the prosecution prior to introducing any of the classified evidence they intend to introduce only serves to increase the likelihood that unclassified information will be designated classified. See Mil. Comm'n Interview 9/13, supra note 57. In the case of 
information, intelligence agencies have in some instances even delegated to commission prosecutors the authority to categorize evidence as classified. This delegation not only increases the incidence of closed courtrooms, but also requires defense counsel to give the government advance notice of the substance of any argument they make in court that might reference evidence the prosecution has deemed classified, regardless of whether the hearing is open to the public. ${ }^{233}$ Given the agency's institutional interest in over-classification, commission judges' lack of authority over classification decisions or release of classified information, and the strategic value to the prosecution of classifying information, it is no surprise that over-classification of evidence in the commission system has reached an all-time high.

The open and amorphous threat of a classification misstepparticularly where classification determinations are strategic and subjective-puts significant pressure on defense counsel to be far more cautious in their advocacy and public statements than lawyers in federal court would be, as well as far more cautious in client communications, an instinct often in tension with a client's best interest. Defense lawyers have been ordered on at least one occasion to keep the identities of prosecution witnesses secret from their own client. ${ }^{234}$ In another instance, defense lawyers were on the receiving end of allegations of leaking the identity of CIA agents to their clients, an allegation later withdrawn by the Department of Justice. ${ }^{235}$ The fear of a ciassification misstep and subsequent government investigation is present in all national security cases but is particularly powerful in military commission court, a system created expressly to give the government wide latitude in protecting classified information and in which commission judges are required to be highly deferential to government

Khalid Sheikh Mohammed, for instance, the government has made the somewhat arbitrary determination that anything Mohammed says or has said meets the definition of "classified." Id.

233. See id.

234. William Glaberson, Witness Names to Be Withheld from Guantanamo Detainee, N.Y. Times, Dec. 1, 2007, available at http://nyti.ms/R5kNgz.

235. See Charlie Savage, Ex-C.I.A. Officer Charged in Information Leak, N.Y. TIMEs, Jan. 23, 2012, available at http://nyti.ms/z1DDFt. The investigation began when 32 pages of photographs were found in the cells of several Guantanamo detainees, photo line-ups of random people and suspected interrogators that the attorneys were using to identify potential witnesses who could testify about detainee abuse as mitigating evidence in their client's death penalty case. Discovery of the photographs caused uproar within the CIA, which initially pressed for an FBI investigation of Guantanamo detainee lawyers. The criminal complaint filed against the alleged source of the leak, a CIA employee, expressly cleared Guantanamo lawyers of wrongdoing. $I d$. 
lawyers and intelligence agencies. ${ }^{236}$ This deterrence to aggressive advocacy not only puts defense counsel in a difficult ethical situation, but also makes conviction more likely than it would be in other forums.

Finally, although the pressure to plead guilty is substantial in every criminal justice system, the pressure to plead guilty in the Guantanamo Bay commission system is unmatched, which brings its own set of ethical challenges for defense counsel. Given the possibility of indefinite detention and, in some cases, the questionable prospect of ever receiving a military commission hearing (a concern heightened by the slow pace of proceedings to date), there is little incentive for any detainee to wait patiently for trial. At the same time, the prospect of indefinite detention is such that the prosecution has little incentive to enter plea negotiations. While the 2008 election of Barack Obama (and his campaign promise to close GTMO) temporarily accelerated the pace of negotiations, there is at present little to no public pressure to process the detainees speedily. ${ }^{237}$ For the terrorist "foot soldiers" held at Guantanamo, individuals who do not pose a significant ongoing threat to national security, who have no ties to prominent defendants, and who are not likely to face any nearterm commission hearing, the ultimate sentence is likely to be far shorter than the period already spent in confinement. Such a result creates both significant pressure to plead guilty and incredibly little bargaining power with which to do so. ${ }^{238}$ When compounded by the government's inability to transfer out of Guantanamo detainees that it may no longer have an interest in holding, the pressure on these detainees to plead guilty-even

236. See supra Part I.C.1 (discussing differences in judicial role under CIPA versus MCA); see also supra Part II.B.2 (discussing how judicial deference, whether perceived or real, impacts prosecutorial decision-making).

237. In a February 2012 Washington Post-ABC News Poll, $70 \%$ of respondents indicated approval of Obama's decision to keep open the Guantanamo Bay detention center. Scott Wilson \& Jon Cohen, Poll Finds Broad Support for Obama's Counterterrorism Policies, WASH. POST, Feb. 8, 2012, available at http://wapo.st/AmGGUx. Although there is little public pressure to swiftly process detainees, commission prosecutors have a strategic interest in securing plea agreements with detainees with ties to Khalid Sheikh Mohammed, the other 9/11 co-conspirators, and al-Nashiri. These detainees, whose testimony helps prosecutors avoid using evidence associated with occasionally torturous interrogations, have a window of time between now and those trials in which they may be able to secure a plea deal by testifying for the prosecution. See, e.g., Peter Finn, Plea Deal in Terror Suspect's Military Trial Sparks Debate, WASH. POST, Mar. 1, 2012, available at http://wapo.st/ApQ2Fe (Mark Martins references ongoing plea negotiations with other GTMO detainees).

238. Those detainees who have been subject to overly aggressive interrogation may have bargaining power once charged (given the likely inadmissibility of their statements to interrogators and the government's interest in concealing its use of tactics some would characterize as torture), but given the prosecution's complete control over who is charged and when-and given the consequence-free alternative of indefinite detention-these detainees' mistreatment gives them little additional leverage in the near-term. 
to crimes for which they may not be responsible-is incredibly high. ${ }^{239}$ Advising a client on a guilty plea is fraught with ethical challenges under even the best circumstances, ${ }^{240}$ but doing so with the limited information and incredibly limited bargaining power extant in the military commission system is particularly challenging. Some detainees have spent over a decade in detention and have no immediate prospects for release. Thus, defense counsel face the choice of convincing their client to plead guilty - potentially to crimes of which they are innocent-in the hope of winning some specified term of confinement, or, in the alternative, leaving their clients, many of whom already struggle with confidence in their lawyers and the commission system, with no recourse but to wait.

Indefinite detention, in particular, ensures that plea bargain negotiations are heavily weighted in the prosecution's favor. Where the alternative to a guilty plea is an indefinite stay at Guantanamo, defense counsel may feel particularly pressured to secure a plea agreement and advise a client to take it, however unfavorable and draconian the terms. For instance, in plea deals ranging from al-Qosi's to Majid Khan's, defense counsel have advised their clients to sign plea agreements that include a provision expressly preserving the government's right to continue holding the detainees indefinitely, even after the agreed-upon sentence has been served. Given the alternative of indefinite or virtually indefinite detention, defense counsel have had little choice but to agree. Majid Khan seemed to sum up defense counsel's common feeling during his guilty plea colloquy, when Judge James Pohl asked him whether he agreed to that specific provision: 'I'm making a leap of faith here, sir, that's all I can do." 241 The pressure to plead guilty raises a host of legal ethical issues for defense counsel that lack any clear resolution and are aggravated by the manner in which the commission system operates.

\section{THE PATH AHEAD}

The ethical challenges and practical difficulties inherent in lawyering in the military commission system implicate the fundamental

239. There is ample literature documenting the systemic pressure to plead guilty to crimes that involve only low-level punishments. MALCOLM M. FEeley, THE Process IS THE PUNISHMENT: HANDLING CASES IN A LOWER CRIMINAL COURT 30, 200-01 (1979); see also Josh Bowers, Punishing the Innocent, 156 U. PA. L. ReV. 1117, 1134-35 (2008); Ian Weinstein, The Adjudication of Minor Offenses in New York City, 31 FordHAM URB. L.J. $1157,1170-75$ (2004).

240. See, e.g., Lee Bridges, The Ethics of Representation on Guilty Pleas, 9 LEGAL ETHICS 80 (2006) (discussing scholarship on legal ethical issues surrounding guilty pleas).

241. Peter Finn, Guantanamo Detainee Majid Khan Pleads Guilty, Promises Cooperation, WASH. POST, Feb. 29, 2012, available at http://wapo.st/Rv0E2C. 
fairness of that system. Although other criminal justice systems occasionally manifest some of the same types of pressures and incentives analyzed above, particularly in high-profile terrorism-related prosecutions, the commission system is unique in terms of the consistency and the magnitude of the ethical conflicts and professional pressures its lawyers face. The commission system aggravates the ethical challenges counsel typically encounter in a terrorism prosecution and makes ethical decision-making more challenging. These ethical challenges each work to disadvantage detainee defendants, favoring conviction in a way not seen in Article III or courts-martial proceedings. Because these challenges result in a justice system slanted toward conviction, a close look at the lawyering in Guantanamo Bay points toward the need for significant reform to the commission system. As detailed above, the structural failings of the commission system that resulted in the early political scandals have not been remedied. Until these failings are resolved, the system will continue to be at risk for political manipulation and will continue to be perceived as such by the JAG lawyers who operate the commissions. Although the military commissions' credibility problem may be on the mend for some domestic critics, ${ }^{242}$ the ethical problems that inhere to the system make clear that the appointment and hard work of highly credentialed, wellreputed personnel ${ }^{243}$ only puts the veneer of fairness on a system that remains fundamentally flawed.

The lack of structural reform to the commissions not only creates a problem with regard to the fairness of GTMO hearings, it also creates problems for the country's counterterrorism efforts. ${ }^{244}$ Indeed, given the international incredulity the military commission system has inspired, the United States has a national and strategic interest in ensuring that the highest standards of ethical conduct are observed in these commission

242. See Editorial Board, A Terrorist's Fair Deal, WASH. Post, Mar. 4, 2012, available at http://wapo.st/zbSBg2 ("For too long, military proceedings at Guantanamo were tragically flawed, unfair both to defendants and to the victims of terrorism. Congress addressed these shortcomings in 2009 by vastly improving military commissions, in large part by shoring up legal protections for defendants."); see also Benjamin Wittes, Darrel Vandeveld on Reformed Military Commissions, LAWFARE BLOG (Mar. 8, 2012, 9:32 PM), http://bit.ly/ArGcgF/ (posting e-mail from former commission critic Darrel Vandeveld, withdrawing his initial opposition to the commission system, as established under the $2009 \mathrm{MCA}$, and attributing his change of heart in part to "a newfound faith in the competence of those who will prosecute, defend, and judge Guantanamo detainees brought to trial in these reformed commissions").

243. See supra note 12.

244. See, e.g., Prasow, supra note 14; Melina Milazzo, Khan Military Commission Conviction Not a Win for America's Justice System, Hum. RTS. FIRST Blog (Mar. 1, 2012), http://bit.ly/yqwsc0. 
proceedings. $^{245}$ Some allies have refused to produce witnesses and evidence or extradite defendants where the military commission system was a possible forum for prosecution. ${ }^{246}$ While military commission advocates tout the commission system's procedural protections as above and beyond those required under international law and used in many European criminal justice systems, ${ }^{247}$ the United States' European allies largely have remained skeptical of the commission system's fundamental fairness. This skepticism is perhaps in part due to potential liability they may face as parties to the European Court of Human Rights for participating in any way in the commission system. ${ }^{248}$

Although the most frequently referenced remedy for the commission system's problems has been a return to Article III courts, Congress's firm opposition to Article III trials for Guantanamo detainees reveals this option as unrealistic. Congress has repeatedly blocked the transfer of Guantanamo detainees to the United States for trial. ${ }^{249}$ Despite President Obama's early commitment to Article III terrorist prosecution, Attorney General Eric Holder has reaffirmed the administration's ongoing commitment to the use of commission courts, and Obama made no repeat of his earlier promise to close GTMO in his recent campaign for reelection. ${ }^{250}$ It is clear that the military commissions are here to stay. Accordingly, the best bet for mitigating the ethical challenges inherent in military commission lawyering likely is to reform the commissions.

245. See, e.g., Vijay M. Padmanabhan, Norm Internalization through Trials for Violations of Law: Four Conditions for Success and Their Application to Trials of Detainees at Guantanamo Bay, 31 U. PA. J. INT'L LAW 427 (2009) (noting international capital to be gained through successful terrorist convictions).

246. See Jordan J. Paust, Serial War Crimes in Response to Terrorism Can Pose Threats to National Security, 35 WM. MITCHELL L. REv. 5201, 5211-12 (2009) ("A senior European Union official . . doubted that any of the 15 [EU] nations ... would agree to extradition that involved the possibility of a military trial.") (citation omitted).

247. See John D. Altenburg, Jr., Military Commissions, in THE LAW OF COUNTERTERRORISM 142, 148 (Lynne K. Zusman ed., 2011).

248. See, e.g., Application, al-Nashiri v. Poland, (Eur. Ct. H. R. May 6, 2011), available at http://bit.ly/T19V7B (application requesting European Court of Human Rights to find that Poland violated al-Nashiri's rights under European law by permitting CIA detention and torture and ultimately permitting his transfer to Guantanamo Bay).

249. See Marty Lederman \& Steve Vladeck, The NDAA: The Good, the Bad, and the Laws of War-Part I, LAWFARE BLOG (Dec. 31, 2011, 4:43 PM), http://bit.ly/uP6WjW (detailing the provisions of the latest Defense Authorization bill, which includes a prohibition on using federal funds to transfer GTMO detainees to the United States for any purpose, effectively prohibiting trial in Article III courts); see also David J.R. Frakt, The Constitutional Clash over Detainees and the Closure of Guantanamo, 74 U. PITT. L. REV. (forthcoming 2012).

250. See Eric Holder, U.S. Att'y Gen., Speech at Northwestern University School of Law (Mar. 5, 2012), available at http://1.usa.gov/y8SorL. 
Legislative reform to the military commission system may be a more realistic solution than abandoning the commissions. However, legislative reform is far from an easy path given the current adversarial political climate. Although Congress responded quickly in both 2006 and 2009 to presidential requests for military commission legislation and reform, moving any legislation through the current divided Congress is likely to be challenging. ${ }^{251}$ But strengthening the military commission process is a goal in which both parties have an interest, and the reforms proposed herein lack some of the guaranteed partisan conflict inherent in reform to evidentiary rules and due process rights. While reforms aimed at increasing or decreasing the procedural protections afforded terrorist suspects would almost certainly be contentious, reforms to protect military lawyers and preserve their professional independence are more likely to receive bipartisan support. This Article proposes increasing the institutional protection afforded military judges, designating a clear body of binding precedent, and requiring congressional confirmation of the Convening Authority. ${ }^{252}$

While courts-martial judges may not require the institutional protections of set terms of service or life tenure, the political pressures inherent in the military commission system make the commission system a different story. Fairly or unfairly, many perceive military judges as favoring the prosecution. ${ }^{253}$ Indeed, military judges, as JAG lawyers and members of the military, face similar ethical pressures to those faced by commission prosecutions and defense counsel. ${ }^{254}$ Accordingly,

251. See generally Olympia J. Snowe, Why I'm Leaving the Senate, WASH. PosT, Mar. 1, 2012, available at http://wapo.st/xQuX9h (observing, after a 17-year career in the Senate, that " $[t]$ he Senate of today routinely jettisons regular order ... serially legislates by political brinkmanship ... and habitually eschews full debate and an open amendment process in favor of competing up-or-down, take-it-or-leave-it proposals").

252. These proposals are clearly not a complete fix for the various institutional and practical problems that inhere to commission lawyering, as detailed in Part II supra. For instance, the lack of oversight and review with regard to classification decisionsexacerbated by the delegation of classification authority to prosecutors in some commission cases - creates significant ethical challenges for both prosecutors and defense counsel. Full exploration of a solution to the classification problem (which plagues both Article III and commission courts) is beyond the scope of this article. It deserves noting, however, that Federal District Court Judge Leonie Brinkema-whose time presiding over the Moussaoui trial and other cases involving voluminous classified information has given her close familiarity with the use and misuse of classified evidence in terrorist prosecution-has suggested that Congress should create an independent government agency that could review cases in which prosecutors and a judge disagree on classification questions. See Kramer, supra note 139.

253. See supra Part II.B.2 (discussing perception of military judges favoring government positions and how this perception impacts prosecutorial decision-making).

254. Military judges do not serve in that capacity indefinitely, as federal judges do. Rather, military judges are JAG lawyers who have been recognized as credentialed to serve as a judge, but who only do so when detailed by the military to a specific case. 
commission judges would not only benefit from the provision of set terms, but also from Congress designating a body of binding precedent upon which they could rely, whether it be UCMJ law or Article III law. ${ }^{255}$ Designating a body of law to serve as commission precedent will not resolve many of the significant legal questions lingering over the military commission system, such as whether constitutional protections apply to detainees. ${ }^{256}$ However, it would provide commission judges with a working body of law to rely upon in resolving some of the many challenging legal questions raised in the commissions on a daily basis. Binding precedent would not only increase legal clarity for the prosecution and defense counsel-providing a stronger basis for their legal arguments and strategy and potentially making Brady decisionmaking slightly easier-it would create more consistency and predictability in commission system rulings, thereby increasing the credibility of the institution among both its practitioners and its observers. Allowing commission judges to draw upon settled law would also reduce accusations and public perception of pro-government bias, and it would provide judges the solid legal support-a clear rule of law-to rely on in making controversial decisions, insulating them from professional risks they may otherwise face if erring in a close call on the side of a Guantanamo defendant.

Moreover, with these additional protections for judicial independence in place, control over defense counsel funding potentially could be transferred from the Convening Authority to the military commission judge, establishing a system more closely analogous to the well-established, and better-insulated, Article III funding process for court-appointed counsel. These reforms would bolster the professional independence of commission judges and defense counsel and increase legal certainty in the system, thereby improving public perception of the system and the system's legitimacy.

The commission system would further benefit from increased insulation from political forces within the Executive Branch. As evidenced by the political pressure exerted on the Chief Prosecutor's Office by Brigadier-General Hartmann and DOD General Counsel

\footnotetext{
When they are not detailed to serve as a judge, military judges serve as JAG lawyers in the same capacity that other JAG lawyers do. As such, all of the same concerns about discipline and professional reputation that influence JAG lawyers would apply equally to military judges. For a discussion of these concerns in the context of JAG prosecutors and defense counsel, see Part II supra.

255. Article III precedent is much more abundant with regard to the areas of law most likely to be relevant to the military commission system and is generally more expansive given its comparative volume and history. Thus, Article III precedent would likely be preferable in this context.
}

256. See, e.g., Vladeck, supra note 6. 
Haynes, and as evidenced by Convening Authority Susan Crawford's effective stonewalling of defense requests for funding, the fact that the commission system has been run by political appointees working with no Congressional oversight has created significant ethical challenges for commission lawyers. Creating a congressional role in the appointment of the Convening Authority would apply a layer of accountability to the selection and conduct of the Convening Authority. Perhaps counterintuitively, inserting Congress into the commission system may actually decrease the politicization of the process, improve the overall perception of the fairness and transparency of the commission system, and ensure that political exigency would be a less controlling factor in decisions about which charges to bring, against whom, and how and with whom to engage in plea bargaining. This process is required for federal judges, U.S. Attorneys, and many other high-level political appointees; thus, instituting it in the commissions is hardly a radical concept. ${ }^{257}$ While adding Congress to any decision-making process brings a degree of politicization to the selection process, requiring Congress to periodically review the system through the confirmation process may inspire more devoted attempts at impartiality from the Convening Authority. Congressional oversight may also discourage future presidents from attempting to appoint a Convening Authority with a clear political agenda that may be at odds with rule-of-law values.

As others have observed, there is no perfect forum for terrorist prosecution, but what is clear from an analysis of the lawyers on the ground is that the military commission system as presently constituted is not the "least worst" alternative pundits had hoped it would be. ${ }^{258}$ While Article III courts have some appeal as the historically tried-and-true

257. While the Appointments Clause limits which appointments Congress may vest power in the President to make, it does not limit Congress's ability to require congressional confirmation of officers' appointments. Hanah Metchis Volokh, The Two Appointments Clauses: Statutory Qualifications for Federal Officers, 10 J. CONST. L. 745,749 (2008). Although the Supreme Court has held that Senate confirmation is not required for military judges, an argument may exist that the standing authority granted to the Convening Authority might require Senate advice and consent, particularly for a civilian appointee. See generally Victor Hansen, Changes in Modern Military Codes and the Role of the Military Commander: What Should the United States Learn from this Revolution?, 16 TUL. J. INT'L \& COMP. L. 419, 446 (2008) (analyzing Weiss v. United States, 510 U.S. 163, 165-66 (1994), which rejected the need for military judge confirmation because (1) Senate advice and consent is given whenever military officers are promoted in rank, (2) there is a long tradition of officer involvement in military justice, and (3) military judges have no inherent judicial authority until detailed to a specific case).

258. Robert Chesney, The Least Worst Venue, ForeIGN POL'Y, Jan. 21, 2011, available at $\mathrm{http} / / / \mathrm{bit} . l y / g L 9 \mathrm{f50}$ ("The Obama administration's plan to resume military commission trials for Guantanamo detainees isn't as terrible as civil liberties advocates think."). 
venue for terrorism prosecution, access to Article III courts for the Guantanamo detainees is currently unrealistic. Accordingly, the most practical solution may be a military commission system that is "revamped" yet again in the ways described above. This approach has practical challenges of its own and is certain to face political obstacles along the way. ${ }^{259}$ Furthermore, congressional agreement on anythingand particularly on national security matters - is no foregone conclusion. Nevertheless, the type of reform advocated herein is of a nature likely to be less contentious than past Guantanamo legislative reform efforts and, among the available options, MCA reform may be best-suited for supporting commission lawyers in their dedication to both the rules of professional responsibility and their military leadership.

\section{CONCLUSION}

The military commission system cannot be trusted to produce credible convictions until the fundamental problems in the system that contribute to its challenging ethical environment are remedied. The prosecution of terrorist suspects presents a host of thorny ethical challenges in any forum, but these challenges are most severe and pervasive in the military commission context. While legal scholars have expended a great deal of ink exploring the political and constitutional problems with military commission prosecution, thus far this body of literature has largely overlooked the lawyers on the ground in Guantanamo Bay. The lesson learned from these lawyers is that, due to institutional identity, political influence, professional disincentives, overclassification, and structural inefficiencies, the significant challenges inherent in terrorist prosecution are amplified in the military commission context and are augmented by unique ethical concerns that do not occur in other forums. A close look at the lawyers on the ground in Guantanamo reveals that there are subtle but identifiable institutional, ethical, and professional pressures at work on the lawyers involved in the Guantanamo Bay military commissions. Taken cumulatively, these pressures materially affect the allocation of justice and due process in that criminal justice system, thereby calling into question the fundamental legitimacy of the commission system and demonstrating the need for further legislative reform.

259. There is no shortage of recent examples of political dysfunction in the U.S. government, as evidenced by the unsuccessful debate in 2011 over raising the debt ceiling and the wrangling last year over the Guantanamo provisions included in the Defense Authorization Act. See, e.g., Press Release, President of the U.S., Statement by the President on H.R. 1540 (Dec. 31, 2011), available at http://1.usa.gov/uUNb0v. 
*** 